\title{
Title
}

\section{Factors affecting Capacity Utilization of Thermal Power (Coal) Plants in India}

\section{Author Information}

\section{Name - A K Tripathi}

Additional General Manager \& Senior Faculty (Strategy), NTPC Regional Learning Institute. (Author is a Mechanical Engineer and MBA in Strategy \& Marketing (Gold Medallist) having 32 years of experience in thermal power generation sector, working in the largest thermal power generation company in India. He has worked in India and in Middle East. Currently he leads the Learning \& Development $(L \& D)$ function in the Western Region of the company. He has presented many papers in national and international forums)

\section{Correspondence - aktripathi04@ntpc.co.in, Mobile -0091-8800441688}

\section{Abstract}

As on 31.03.2020, 55.4\% (205135 MW) of total installed capacity (370106 MW) in India is through coal and lignite based power plants. These plants, set up by central, state and private utilities with substantial capital investment are facing consistently reducing Plant Utilization Factor (known as Plant Load Factor, PLF, in India). In the year 201920 the national average thermal power PLF stood at 55.4\%, down from $78.6 \%$ in 2007-08. On the other hand, the electricity demand is consistently rising in the country and there exists a peak and energy shortage at national level. In 2019-20 energy shortage was $0.7 \%$ and peak shortage was $0.5 \%$. A disturbing paradox therefore exists here. On one hand, the country is power deficit, and on the other hand, a large amount of coal based affordable power, ready to be generated by thermal power generators, remains grossly unused. Looking into the fact that considerable investment has gone into developing these thermal power generation assets in the country, the falling PLF is a matter of concern for all the key stakeholders including the power producers, lenders, regulators and consumers. This paper identifies seven major factors that are affecting PLF of thermal power plants and then makes an attempt to project future scenario of PLF so that critical stakeholders can intervene through appropriate actions. Primary research with responses from power professionals has been used to find out the major factors. Future projection of PLF has been done using Partial Least Square (PLS) regression. Projection shows that in the Business As Usual case (Factors increasing at the current CAGR rate), the thermal power plants will face very low level of PLF (14.76 \%) by 2024-25. This will mean that many plants will be shut down and many will run for only few hours in a day that too at very low loads. If the future generation mix is kept as indicated by Central Electricity Authority (CEA), a Govt. of India in its report (Draft report on optimal generation capacity mix for 2029-30- CEA-Govt of India) then the thermal power plant average PLF can sustain above $68 \%$ until 2024-25. If followed, this path can be a breather for the thermal power plants.

\section{Key Words}

Thermal, Power Plant, Utilization Factor, Plant Load Factor, PLF, Generation Mix, Renewable, Future, Declared Capacity, NTPC, Energy, Peak, Deficit, Environment, India 


\section{Introduction}

\subsection{Impressive growth of thermal power installed capacity in India}

Indian power sector has seen an impressive growth in installed power capacity since independence of the country. Total installed capacity rose from nearly $1000 \mathrm{MW}$ (as on 31st March 1947) to $370106 \mathrm{MW}$ (as on 31.03.2020). The two tables below (Table and 02) depict the current fuel wise breakup of installed capacity (as on 31.03.2020), (Table $01)$ and how installed capacity has grown over years (Table 02)-

Table - 01

\begin{tabular}{|c|c|c|}
\hline Fuel & MW & $\%$ of Total \\
\hline Total Thermal & $2,30,600$ & $62.8 \%$ \\
\hline Coal & $1,98,525$ & $54.2 \%$ \\
\hline Lignite & 6,610 & $1.7 \%$ \\
\hline Coal + Lignite & 205135 & $55.4 \%$ \\
\hline Gas & 24,937 & $6.9 \%$ \\
\hline Diesel & 510 & $0.1 \%$ \\
\hline Hydro (Renewable) & 45,699 & $12.4 \%$ \\
\hline Nuclear & 6,780 & $1.9 \%$ \\
\hline RES* (MNRE) & 86,028 & $23.5 \%$ \\
\hline Total & 370,106 & \\
\hline
\end{tabular}

Installed Capacity in India as on 31.03.2020, Source- Government of India, Ministry of Power, CEA, [1, 2, 3, 4, 5]

\subsection{Growth of power generation capacity in India 1947- 2020}

Following table (Table 02) shows the fuel wise installed capacity since 1947. Starting from a meagre $1362 \mathrm{MW}$ in 1947, the total installed power capacity has risen to 370106 MW by the end of March 2020. Major contributor to this growth has been coal based generation capacity. Out of the $370106 \mathrm{MW}$ as on 31.03 .2020 , coal based capacity is 205135 MW, which makes $55.4 \%$ of the total capacity. Looking at the past ten years, the coal based generation has increased rapidly till 2016 (13.39 \% CAGR between 2010-11 to 2016-17), but then it slowed down after $2016-17$ (2.2 \% CAGR between 2016-17 to 2019-2020). Renewables, on the other hand, have been rising sharply in this period (14.86 \% CAGR between 2016-17 to 2019 -20)

Table- 02

\begin{tabular}{|c|c|c|c|c|c|c|c|c|c|c|}
\hline \multirow[b]{2}{*}{$\begin{array}{l}\text { Sl } \\
\text { No. }\end{array}$} & \multirow[b]{2}{*}{ As On } & \multirow[b]{2}{*}{ Year } & \multirow[b]{2}{*}{ Hydro } & \multicolumn{3}{|c|}{ Thermal } & \multirow[b]{2}{*}{ Total } & \multirow[b]{2}{*}{ Nuclear } & \multirow[b]{2}{*}{$\begin{array}{l}\text { RES* } \\
\text { (MNRE) }\end{array}$} & \multirow[b]{2}{*}{ Total } \\
\hline & & & & $\begin{array}{l}\text { Coal/ } \\
\text { Lignite }\end{array}$ & Gas & Diesel & & & & \\
\hline 1 & 31.12 .1947 & 1947 & 508 & 756 & 0 & 98 & 854 & 0 & 0 & 1362 \\
\hline 2 & 31.12 .1950 & 1950 & 560 & 1004 & 0 & 149 & 1153 & 0 & 0 & 1713 \\
\hline 3 & 31.03 .1956 & 1956 & 1061 & 1597 & 0 & 228 & 1825 & 0 & 0 & 2886 \\
\hline 4 & 31.03 .1961 & 1961 & 1917 & 2436 & 0 & 300 & 2736 & 0 & 0 & 4653 \\
\hline 5 & 31.03 .1966 & 1966 & 4124 & 4417 & 134 & 352 & 4903 & 0 & 0 & 9027 \\
\hline 6 & 31.03 .1969 & 1969 & 5907 & 6640 & 134 & 276 & 7050 & 0 & 0 & 12957 \\
\hline
\end{tabular}




\begin{tabular}{|l|l|l|l|l|l|l|l|l|l|l|}
7 & 31.03 .1974 & 1074 & 6966 & 8652 & 165 & 241 & 9058 & 640 & 0 & 16664 \\
\hline 8 & 31.03 .1979 & 1979 & 10833 & 14875 & 168 & 164 & 15207 & 640 & 0 & 26680 \\
\hline 9 & 31.03 .1980 & 1980 & 11384 & 15991 & 268 & 165 & 16424 & 640 & 0 & 28448 \\
\hline 10 & 31.03 .1985 & 1985 & 14460 & 26311 & 542 & 177 & 27030 & 1095 & 0 & 42585 \\
\hline 11 & 31.03 .1990 & 1990 & 18307 & 41236 & 2343 & 165 & 43764 & 1565 & 0 & 63636 \\
\hline 12 & 31.03 .1992 & 1992 & 19194 & 44791 & 3095 & 168 & 48054 & 1785 & 32 & 69065 \\
\hline 13 & 31.03 .1997 & 1997 & 21658 & 54154 & 6562 & 294 & 61010 & 2225 & 902 & 85795 \\
\hline 14 & 31.03 .2002 & 2002 & 26269 & 62131 & 11163 & 1135 & 74429 & 2720 & 1628 & 105046 \\
\hline 15 & 31.03 .2007 & 2007 & 34654 & 71121 & 13692 & 1202 & 86015 & 3900 & 7760 & 132329 \\
\hline 16 & 31.03 .2012 & 2012 & 38990 & 112022 & 18381 & 1200 & 131603 & 4780 & 24504 & 199877 \\
\hline 17 & 31.03 .2013 & 2013 & 39491 & 130221 & 20110 & 1200 & 151531 & 4780 & 27542 & 223344 \\
\hline 18 & 31.03 .2014 & 2014 & 40532 & 145273 & 21782 & 1200 & 168255 & 4780 & 31692 & 245259 \\
\hline 19 & 31.03 .2015 & 2015 & 41267 & 164636 & 23062 & 1200 & 188898 & 5780 & 35777 & 271722 \\
\hline 20 & 31.03 .2016 & 2016 & 42783 & 185172 & 24508 & 993 & 210675 & 5780 & 45924 & 305162 \\
\hline 21 & 31.03 .2017 & 2017 & 44478 & 192163 & 25329 & 838 & 218330 & 6780 & 57260 & 326848 \\
\hline 22 & 31.03 .2018 & 2018 & 45293 & 197171 & 24897 & 838 & 222907 & 6780 & 69022 & 344002 \\
\hline 23 & 31.03 .2019 & 2019 & 45399 & 200704 & 24937 & 637 & 226279 & 6780 & 77641 & 356100 \\
\hline 24 & 31.03 .2020 & 2020 & 45699 & 205135 & 24937 & 510 & 230582 & 6780 & 87028 & 370106 \\
\hline
\end{tabular}

Growth of power generation capacity in India 1947- 2020. Source- Government of India, Ministry of Power, CEA, Website $[1,2,3,4,5]$

\subsection{Plant Utilization Factor (PUF) or Plant Load Factor (PLF) of Thermal Power Plants}

The Plant Utilization Factor or Plant Utilization Factor (PUF) of a given period, known more commonly in India as Plant Load Factor (PLF) (hereinafter term PLF has been used for describing Plant Utilization Factor in this paper) is the ratio expressed in percentage terms, of actual energy generated by the power plant to the notional energy generated by the plant if it were operating at its full rated capacity. This ratio therefore indicates how well the generation asset is being utilised. If the plant operates at full capacity in the entire year, the PLF of the year will be $100 \%$. However, over a period of one year, generally a plant would not achieve $100 \%$ PLF because of various reasons. The reasons could be many, like - the plant being under forced shutdown (Forced Outage) due to equipment problems, being shut down for routine maintenance (Planned Outage), shut down due to non-availability of fuel (coal), not being able to generate at full capacity because of lower requisition of power by purchasing utilities, compulsion to reduce generation when renewable energy is available in the grid to cater to the demand (because renewable energy has must run preferential status to generate and sell power first in the grid, others have to reduce generation), etc. Technically, for a properly maintained plant, the Forced Outage and Planned Outage together account for around 8-9 \%, which together bring a reduction in PLF by 8-9 \% in a year. Therefore, a reasonably healthy power plant should be able to operate at 91-92\% Utilization Factor (PLF) if other factors are favourable. However, the following figure (Figure-01) depicts a disturbing trend. As can be seen, PLF of thermal power has been falling consistently in last 12 years. National average PLF in the year 2019-20 was $55.4 \%$ 


\section{PLF of thermal power plants in the country (Coal \& Lignite based) from 1985-86 to 2019-20 is as under:}

Figure - 01

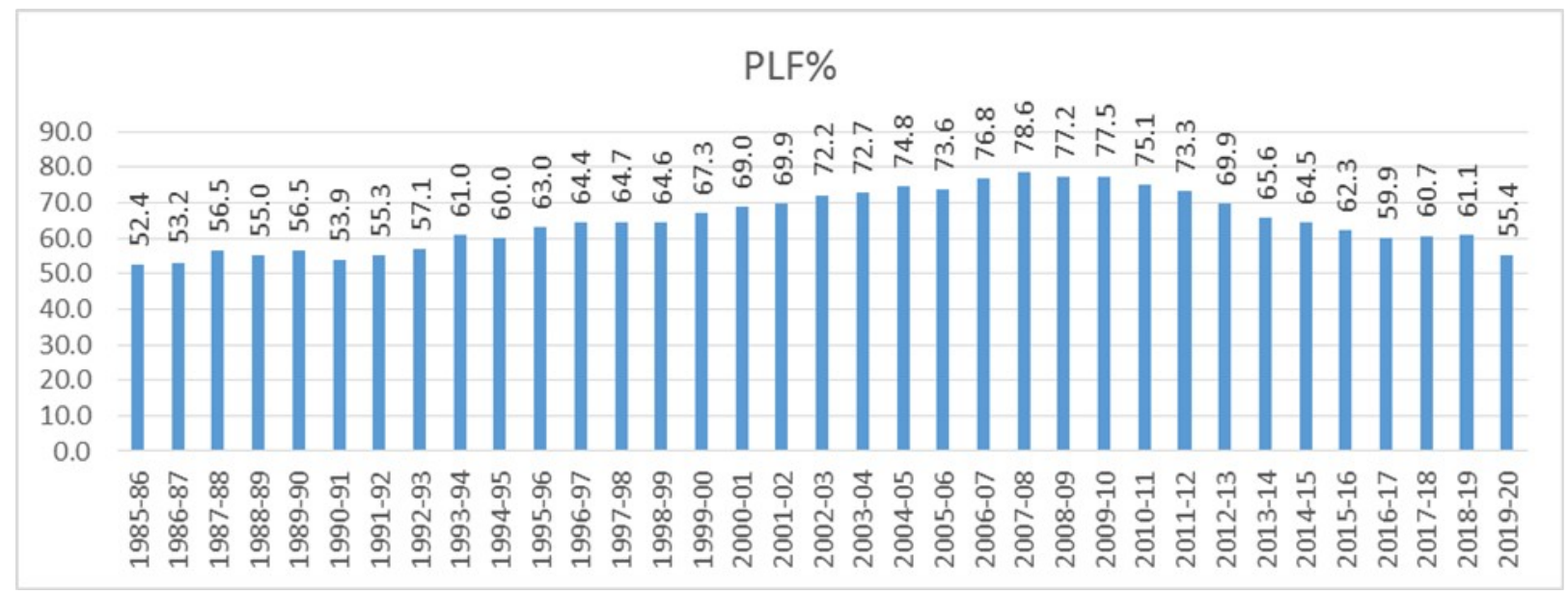

PLF of thermal power plants in India 1885-86 to 2019-20- - Source- Central Electricity Authority, New Delhi, Power Sector Report, 1947-2015 development of power sector and Ministry of Power [1, 2, 3, 4, 5]

It is also pertinent to note that this drop in Plant Utilization Factor or PLF of coal stations is happening across the sectors (Central, State and Private sector power plants) which is evident from the following table (Table 03). It can also be seen that central sector plants have maintained highest PLF, followed by Private and State sector. On average basis (taking data of 11 years as below), Central sector plants have maintained higher PLF than national by about $10.08 \%$, the State sector is lower than national PLF by $5.55 \%$ and Private sector is lower than national PLF by $2.13 \%$.

Table - 03

\begin{tabular}{|c|c|c|c|c|}
\hline \multirow[b]{2}{*}{ Year } & \multirow[t]{2}{*}{ National PLF \% } & \multicolumn{3}{|c|}{ Sector-wise PLF (\%) } \\
\hline & & Central & State & Private \\
\hline $2009-10$ & 77.5 & 85.5 & 70.9 & 83.9 \\
\hline $2010-11$ & 75.1 & 85.1 & 66.7 & 80.7 \\
\hline 2011-12 & 73.3 & 82.1 & 68.0 & 69.5 \\
\hline $2012-13$ & 69.9 & 79.2 & 65.6 & 64.1 \\
\hline $2013-14$ & 65.60 & 76.10 & 59.10 & 62.10 \\
\hline $2014-15$ & 64.46 & 73.96 & 59.83 & 60.58 \\
\hline $2015-16$ & 62.29 & 72.52 & 55.41 & 60.49 \\
\hline 2016-17 & 59.88 & 71.98 & 54.35 & 55.73 \\
\hline $2017-18$ & 60.67 & 72.35 & 56.83 & 55.32 \\
\hline 2018-19 & 61.07 & 72.64 & 57.81 & 55.24 \\
\hline $2019-20$ & 56.08 & 65.36 & 50.26 & 54.73 \\
\hline Average of 11 Years & 65.99 & 76.07 & 60.43 & 63.85 \\
\hline
\end{tabular}

Sector wise plant Utilization Factor (PUF or PLF) of thermal power plants in India - Source- Government of India, Ministry of Power and CEA $[1,2,3,4,5]$

For critical infrastructure sector like electricity, where large capital-intensive projects are set up, one of the important 
considerations is that the capacity utilization should be optimal. This is to ensure that the assets created with enormous cost are utilised optimally, electricity prices are kept optimal and there are reasonable returns generated for thermal power generators to sustain investment in new assets.

\subsection{Energy and Peak Demand Deficits in India}

The robust growth of power generation installed capacity in the country was propelled by the demand and supply gap of electricity. The following table gives energy and peak shortages of power in the country since 2009-10. It is clear from the data that the country has consistently faced energy and peak shortages. In the year 2019-20, energy shortage was $0.5 \%$ of the demand and peak shortage was $0.7 \%$ of the demand.

Table-04

\begin{tabular}{|c|c|c|c|c|c|c|c|c|}
\hline \multirow{3}{*}{ Year } & \multicolumn{4}{|c|}{ Energy } & \multicolumn{4}{|c|}{ Peak } \\
\hline & \multirow{2}{*}{$\begin{array}{l}\text { Requiremen } \\
\mathrm{t} \\
(\mathrm{MU})\end{array}$} & \multirow{2}{*}{$\begin{array}{l}\text { Availabili } \\
\text { ty } \\
\text { (MU) }\end{array}$} & \multicolumn{2}{|c|}{$\begin{array}{l}\text { Surplus(+)/ Deficts } \\
(-)\end{array}$} & \multirow{2}{*}{$\begin{array}{l}\text { Peak } \\
\text { Demand } \\
(\mathrm{MW})\end{array}$} & \multirow{2}{*}{$\begin{array}{l}\text { Peak Met } \\
\text { (MW) }\end{array}$} & \multicolumn{2}{|c|}{ Surplus(+) / Deficts(-) } \\
\hline & & & (MU) & $(\%)$ & & & (MW) & $(\%)$ \\
\hline $2009-10$ & $8,30,594$ & $7,46,644$ & 83,950 & -10.1 & $1,19,166$ & $1,04,009$ & 15,157 & -12.7 \\
\hline $2010-11$ & $8,61,591$ & $7,88,355$ & 73,236 & -8.5 & $1,22,287$ & $1,10,256$ & 12,031 & -9.8 \\
\hline $2011-12$ & $9,37,199$ & $8,57,886$ & 79,313 & -8.5 & $1,30,006$ & $1,16,191$ & 13,815 & -10.6 \\
\hline $2012-13$ & $9,95,557$ & $9,08,652$ & 86,905 & -8.7 & $1,35,453$ & $1,23,294$ & 12,159 & -9.0 \\
\hline $2013-14$ & $10,02,257$ & $9,59,829$ & 42,428 & -4.2 & $1,35,918$ & $1,29,815$ & 6,103 & -4.5 \\
\hline $2014-15$ & $10,68,923$ & $10,30,785$ & 38,138 & -3.6 & $1,48,166$ & $1,41,160$ & 7,006 & -4.7 \\
\hline $2015-16$ & $11,14,408$ & $10,90,850$ & 23,558 & -2.1 & $1,53,366$ & $1,48,463$ & 4,903 & -3.2 \\
\hline $2016-17$ & $11,42,929$ & $11,35,334$ & $-7,595$ & -0.7 & $1,59,542$ & $1,56,934$ & 2,608 & -1.6 \\
\hline $2017-18$ & $12,12,134$ & $12,03,567$ & $-8,567$ & -0.7 & $1,64,066$ & $1,60,752$ & $-3,314$ & -2.0 \\
\hline $2018-19$ & $12,74,595$ & $12,67,526$ & $-7,070$ & -0.6 & $1,77,022$ & $1,75,528$ & $-1,494$ & -0.8 \\
\hline $2019-20$ & $12,90,247$ & $12,83,690$ & $-6,557$ & -0.5 & $1,83,804$ & $1,82,533$ & $-1,271$ & -0.7 \\
\hline
\end{tabular}

Energy and Peak Deficit in India - Source- Government of India, Ministry of Power and Central Electricity Authority (CEA) websites [3]

Under the above background of energy and peak shortages the falling PLF (Table 03) presents a paradox which is the subject matter of work in this paper.

\section{Business Problem}

A recent phenomenon called Un- Requisitioned Surplus (URS) indicates the business problem vividly. When a power procuring utility does not requisition power that it had originally contracted to procure from a generating station - it results in the plant running on low PLF thus resulting in unsold electricity for the generator which is termed as Un-Requisitioned Surplus (URS). This is the electricity, power producer is ready to generate but could not generate because the buyer did not requisition it. In 2019-20, in one year alone, the largest power producer of the country NTPC could not generate and sell more than 74000 MUs (URS) [6] of electricity whereas in the same year $0.5 \%$ peak energy deficit and $-0.7 \%$ peak deficit was reported at the national level. Demand and supply data given in table 04 above clearly shows that India has always remained a power deficit nation. (There exists, also, another 
substantial demand which is not yet accounted in the deficit calculation - demand where electricity has not reached the consumers like, un-electrified households, un-electrified farms and un-electrified remote rural areas.. Such demand obviously remains out of this estimation.)

This situation shows a clear paradox here - On one hand there is Un-Requisitioned Surplus Electricity (Remaining unsold by the power producer), on the other hand electricity deficit persists in the country.

Many new, modern technology, high efficiency, supercritical thermal power plants are either running at abysmally low Utilisation Factor (PLF) or are kept under shut down. To understand the problem in better perspective, the example of Capacity Utilization (PLF) of thermal power plants of NTPC, a Govt. of India company, which is the largest power producer in India is depicted below in Table 05. The table shows the difference between Plant Load Factor (PLF) and Declared Capacity (DC) for NTPC.

The Declared Capacity (DC) of a power plant is the capacity in percentage terms at which the plant is ready to generate power. DC is declared by the power producing plant so that the power purchaser can send its requisition accordingly. Such requisition is called the Schedule. If the purchaser does not buy the full Declared Capacity (DC) of the plant it will result in the plant running at lower than the Declared Capacity (DC), hence the Utilization Factor (PLF) shall be lower than the DC. This difference creates the Un-Requisitioned Surplus (URS).[6]

The Table 05 below, shows clearly that NTPC plants were scheduled much below their Declared Capacity and PLF was below DC.

Table-05

\begin{tabular}{|l|l|l|l|}
\hline Year & $\begin{array}{l}\text { PLF (\%) } \\
\text { (Coal Stations) }\end{array}$ & $\begin{array}{l}\text { Declared } \\
\text { Capacity (DC) (\%) }\end{array}$ & $\begin{array}{l}\text { Difference } \\
\text { (DC-PLF)- \% }\end{array}$ \\
\hline $2005-06$ & 87.52 & 89.74 & 2.22 \\
\hline $2006-07$ & 89.43 & 91.12 & 1.69 \\
\hline $2007-08$ & 92.24 & 93.86 & 1.62 \\
\hline $2008-09$ & 91.14 & 92.23 & 1.09 \\
\hline $2009-10$ & 90.81 & 91.41 & 0.6 \\
\hline $2010-11$ & 88.29 & 91.67 & 3.38 \\
\hline $2011-12$ & 85.00 & 88.35 & 3.35 \\
\hline $2012-13$ & 83.08 & 87.62 & 4.54 \\
\hline $2013-14$ & 81.50 & 91.79 & 10.29 \\
\hline $2014-15$ & 80.23 & 88.69 & 8.46 \\
\hline $2015-16$ & 78.61 & 92.29 & 13.68 \\
\hline $2016-17$ & 78.59 & 92.88 & 14.29 \\
\hline $2017-18$ & 78.99 & 87.88 & 8.89 \\
\hline $2018-19$ & 76.81 & 87.63 & 10.82 \\
\hline $2019-20$ & 68.20 & 89.36 & 21.16 \\
\hline
\end{tabular}

PLF and Declared Capacity of NTPC - Source - NTPC Performance Data [6]

As can be noticed above, the difference between Declared Capability and PLF has increased from $2.22 \%$ in the year 2005-06 to whopping $21.16 \%$ in the year 2019-20. This is staggering increase and is worrisome. The above situation results in considerable amount of electricity not being sold/utilised (URS) thus reducing the revenue of the generator. As brought out earlier, NTPC, country's largest and premier thermal power generator which runs power plants at high 
efficiency, could not generate and sell more than 74000 MUs of electricity in one year (2019-20) alone, due to this phenomenon. This amounts to about $25 \%$ of the total generation (300 Billion Units) that the company sold to the customers that year. It amounts to demand remaining unserved somewhere in the country when power was available with the generator.

Lower PLF also means that plants are operating at suboptimal level (Average national PLF was 55.42 \% in 2019-20), with operating parameters worse than design/normative limits (Norms fixed by the Electricity Regulator), thus causing loss to the generator. For example, the electricity regulator fixes the normative Heat Rate for various types of power stations. Heat Rate is a measure of efficiency and represents how much heat energy is consumed by the power plant to generate one unit of electricity. Higher the heat consumption per unit of electricity produced, higher is the Heat Rate and lower is the efficiency and vice versa. The normative efficiency level (Heat Rate) has been fixed by the electricity regulator for each plant. The efficiency levels (Heat Rate) were fixed by the regulator based on design values of plants (with some allowances for deterioration), when plants are supposed to run at near full load. The energy charges that the thermal power generator receives through tariff (Energy charge is the charge which remunerates the power producer for the cost of fuel burnt) is based on presumption that the plant is running at this specified efficiency level (Normative level). If the producer operates at efficiency levels worse than this normative limit, it could incur losses on this account.

When plants run on low PLF, the efficiency level may drop below this normative level. This means that plant will run with efficiency worse than normative (Heat Rate higher than normative). This, inter alia, means that the producer will spend more on fuel but will get less through energy charge of electricity. Every unit sold in this situation will be at loss. Realising this difficulty, at the representation of thermal power generators, the regulator has permitted some allowance in the normative Heat Rate so as to compensate the generators for such loss. However, the allowances are still not adequate as the PLF is going down day by day and in many power plants the Heat Rate goes worse than normative Heat Rate.

In this context, it is also pertinent to have a look at the way electricity is purchased/sold in the bulk electricity market in India. Electricity is mainly (about 88 \%) sold through long term Power Purchase Agreements (PPAs) between the power producers and the power purchasing entities. i.e the state distribution companies (Discoms), Dash Jayajit, Business Standard (2019, July 15) [7]. Having secured their total requirement of power through long term agreements, the Discoms buy power from the contracted power plants through merit order mechanism. That simply means that the cheaper power gets bought/scheduled first and the next costlier one gets bought next, until demand is met.

In this merit order system, there is policy support available to renewable energy. The renewable energy has a preferential treatment under the "must run" status. The purchasing entities, Discoms, are under obligation to buy renewable energy first, even if it is costlier than thermal or any other competing form. A certain percentage of their total electricity purchase has to come from renewable energy under "Renewable Purchase Obligation, (RPO)". Recently, Ministry of Power, Government of India, in June 2018, has notified the long term trajectory of RPOs for 
solar as well as non-solar for next three years from 2019 - 20 to 2021 - 22, reaching $21 \%$ of RPO by 2022 , with share of solar being $10.50 \%$.( Financial Express, (2018, June 16) [8] )

Kashish Shah, energy analyst with IEEFA (Power Engineering International, 2020) [9] reports that there is already a slowdown in new capacity addition. In the last 12 months to January 2020, $46 \mathrm{GW}$ of coal-fired power projects were formally or informally cancelled. However, $37 \mathrm{GW}$ still under construction. Under this already tight situation for thermal power generation, around $37 \mathrm{GW}$ of new thermal power plants are further in the pipeline (As on March 23, 2020). These pipeline projects, along with fast upcoming new renewable plants, which get presence in scheduling for obvious advantage of being green energy, will push thermal generators to even more difficult situation at a time when demand growth in the country is not very robust.

ET, Dec 20, 2016 [10] report states that if average PLF falls below 48\% by 2022 then many coal-based projects may also run into financial difficulty. These projects are financed mainly (75-80\%) through loans. Interest on loans must be paid even if plants remain idle. This can jeopardise many projects, hugely burdening the developers and lenders.

This situation requires that we urgently find and focus on the factors responsible for falling Utilization Factor (PLF) of thermal power stations, so that policy makers, power producers, power purchasing companies, consultants and other key stakeholders can take appropriate action to manage the situation optimally. In this paper we explore various factors responsible for such situation and future scenario.

\section{Materials \& Methods}

\subsection{Literature Review}

Literature review consisted of a study of published papers, articles, including those published in Energies, Govt. policy documents, national and international journals, journal websites and websites of Ministry of Power, CEA, NTPC Data, National Electricity Policy, Regional Load Dispatch Center, Ministry of New and Renewable Energy, Conference Proceedings and Presentations etc. ProQuest was used to access the scholarly articles and papers.

Substantial work has been in the area of renewable energy integration in the grid and its consequent effect on thermal power. Papers in this arena have dealt mainly with merits of renewable energy and have looked into how these could be integrated into the grid and how this integration will impact coal plants.

One of the most relevant work in this field comes from Wang, P., \& Li, M. (2019) [11]. They have done scenario analysis in the electric power industry in China under the implementation of the electricity market reform and a carbon policy in China. They have modelled four potential influencing factors of government policy: (1) the demand response mode; (2) power marketization process; (3) capacity adjustment of thermal power units; and (4) carbon taxes, which vary in terms of their timing and amount. Their model assesses the impact of these influencing factors on the competition between electricity generators using a range of output variables, including generation portfolios, electricity prices, capacity factors, $\mathrm{CO}_{2}$ emissions, etc. Two scenarios have been considered, Business as Usual (BAU) and Aggressive Demand Response (AG). The results show that the new round of electricity market reforms

$$
P \text { a g e } 8 \text { | } 46
$$


has had a positive impact on renewable energy generation. The Business As Usual case predicts that Utilization Factor (UF or PLF) of thermal power shall drop considerably from $42 \%$ in 2020 to $28 \%$ in 2035 . They predict that thermal power capacity addition will have negative growth of $0.004 \%$ during 2030-35. The modus of China's future electricity generation is divided into two parts, under electricity marketization, in this model: the first part is the "equal shares" dispatch generation for the planned electricity sector, whereby all types of power generation technologies comply with the "equal shares" electricity generation rules; the second part entails the "economic optimization" dispatch generation for the electricity market sector, which is under an economic optimization algorithm that selects the lowest-cost option for electricity generation. The output of the model indicates the pathway of China's power sector under different policy scenarios over the planning horizon, including the power generation profiles, capacity factors of various power generation technologies.

Wang, Y., \& Chen, J. (2019) [12], have addressed the issue of continuous reduction in utilisation of thermal power generating capacity in China. They have studied the interaction between installed capacity and utilization of power sector into the dynamic spatial Durbin model, and estimated the specific impact on carbon dioxide emissions from the power sector, based on the panel data set of China's provinces during 1991-2015. The results show that both installed capacity and utilization rate have positive effects on $\mathrm{CO} 2$ emissions. As a result, dissolving overcapacity of thermal power generation and a necessary interprovincial coordination will promote carbon emission reduction rather than investing in coal-fired power plants, and the power authority should turn to alternative investment in cleaner power generation technologies.

Another important work comes from Germany. Robert, K. S. (2019) [13] has analysed hourly generation patterns at large coal-fired units and implications of transitioning from baseload to load-following electricity supplier. The paper states that several factors have led to the decline of electricity generation from coal over the past decade, and projections forecast high rates of growth for wind and solar technologies in coming years. Robert's analysis uses hourly generation data from large coal-fired power stations to determine how operations have been modified in recent years and describes the implications of these changes for plant equipment and unit reliability. The data shows increasing variability in intraday generation output and the high degree of potential impact on coal plant equipment. The study suggests the development of a new modelling tool that will represent the costs of running coalfired power plants at lower capacity factors.

Luo, G., Zhang, X., Liu, S., Dan, E., \& Guo, Y. (2019) [14] have brought out the effect of renewable energy on thermal power generation and have analysed the demand for flexibility improvement of thermal power units for accommodation of wind power under the situation of high-proportion renewable integration.

Liao, S., Li, Z., Li, G., Wang, J., \& Wu, X. (2015) [15], have done modelling and optimization of the medium-term units commitment of thermal power. They have created a scheme for thermal power plants under the name Mediumterm Optimal Commitment of thermal units (MOCTU) to ensure that the generation process runs smoothly and minimizes the start-up and shut-down times of thermal units. This paper also therefore deals with effect of renewable energy on thermal power plants and how they should embrace the flexible operation regime. 
Bhardwaj, N., \& Sharma, D. (2020) [16] have analysed the financial sustainability of Indian power sector, particularly in terms of poor financial health of the electricity distribution companies in India. They have discussed the poor state of financial health of the distribution companies and the mounting losses that these entities are suffering. Further, they state that distribution sector is revenue generating link which makes it essential to convert these loss incurring utilities into profit ones so that it can cope up with rising energy demand.

Singh, S. K., Bajpai, V. K., \& Garg, T. K. (2013) [17] have studied the changes in productivity for 25 stateowned coal-fired power plants (CFPPs) in India, over a period of seven years (2003-2010). This study recommends specific policies that can be implemented to increase the productivity of power plants. In this study, authors have opted DEA-based MPI approach to measure the productivity change (TFP) over a period of time (2003-2010). This study finds that ageing and lack of renovation and modernisation could be a factor responsible for low productivity of plants. The study also provides an overview of Indian CFPPs that can aid energy planners and plant operators in the monitoring and detection of changes in productivity.

There are two very important reference works relevant for this research coming from the advisory bodies/agencies related to Govt of India. One is the Draft National Electricity Plan, Volume I ; (Central Electricity Authority, (CEA) ; Dec 2016) [18] and the other is Greening the Grid: Pathways to Integrate 175 Gigawatts of Renewable Energy into India's Electric Grid, Vol. I-National Study, a Joint Initiative by USAID and Ministry of Power [19].

The Draft National Electricity Plan from CEA [18] (A Govt of India agency, vested with planning in the Power Sector) discusses the issue of Capacity Utilization of thermal power plants in India. It has predicted that by 2022 many plants may get partial or no schedule of generation at all, meaning that many of these thermal power plants may have to be kept idle for lack of demand. Technical viability of thermal plants becomes dicey if they run under 55\% Capacity Utilization. The CEA Plan also adds that in order to accommodate high quantum of renewable energy into the grid, thermal plants are likely to run at low Plant Load Factor (Capacity Utilization) in future. It further suggests that a market mechanism through regulatory intervention needs to be evolved so that the owners of thermal plants are able to recoup the investment and, at the same time, customers are not unnecessarily burdened with high tariff.

Greening The Grid [19] is an extensive study covering operational challenges and cost saving opportunities for renewable energy using state- of-the-art power system planning tools. This paper discusses in detail the integration of renewable and also discusses flexibilisation requirement of thermal power plants in India.

There are many articles from prestigious news publications in India which have cited that the Utilization Factor (PLF) of thermal power plants in India is going down and likely to drop further. They have also brought out some of the factors behind such drop in Utilization Factor.

The Hindu Business Line ( 2017) [20], prestigious news publication in India reports that the coal 'supply constraint' has affected are thermal power plants, which are facing severe coal shortage and are running at less than half-a-day's stocks. 
Anupam Chatterjee, Financial Express, 2018 [21] has pointed out that lower-than-expected growth in demand for electricity, coupled with the overcapacity of installed power projects, has precipitated a situation where more than 20,000 MW of under-construction coal-based power projects in the private sector are staring at an uncertain future.

Sengupta, D. The Economic Times (2016, Dec 20) [10] predict that thermal power plants' Capacity Utilization in India will drop to $48 \%$ by 2022 . It further adds that all coal-based thermal power plants need to brace for a drastic fall in Capacity Utilization by 2022, as additional non-thermal (renewable) electricity generation capacities come on stream. At that level of utilisation, plants may lose the ability to run at a technically viable level and might find it extremely difficult to service debts turning into non-preforming assets for lenders.

A report in Mint (2018, June 12)[22], another prestigious newspaper dedicated to economic news, reports that Renewable Energy might be responsible for falling Utilization Factor of thermal power plants. It says that Renewable energy may have taken "some of the wind out of the sails" of the thermal power sector. However, it affirms that considering the fact that thermal power caters to most of India's electricity needs at present and a limited number of plants are being built or are in the pipeline, the country may end up in a tight supply situation in three-four years if battery storage does not become cost-effective (making renewable energy accessible round the clock). It adds that renewable energy has become quite competitive due to falling project costs, but lack of affordable battery storage solutions means thermal power continues to cater to the core base demand.

Prasad, R. (2015, Jul 20) [23] point out that addition of new capacities in the thermal power sector, lack of fuel and then low demand from buyers has forced thermal power generators to run below optimal capacity.

Energy Monitor Worldwide, (2016, Dec 21) [24] says that all coal-based thermal power plants need to brace for a drastic fall in Capacity Utilization to as low as $48 \%$ by 2022 , as additional non-thermal electricity generation capacities come on stream. It warns that at that level of utilisation, they may lose the ability to run at a technically viable level and might find it extremely difficult to service debts turning into non-preforming assets for lenders.

Xue, Y., \& Xiao, S. (2013) [25] point out towards generalized congestion of power systems of India which affects the adequacy and security. The researchers bring in term as generalized congestion. This generalised congestion might a constraint in effective and efficient utilisation of generation assets.

All relevant literature on the subject has been examined to explore factors affecting thermal power generation. It is found that most literature has identified or focussed on one or two factors that affect Capacity Utilization of thermal power plants. Moreover, in terms of impact and projections about thermal power, most work is focussed on how to support and integrate renewables in the grid. The study of effect on thermal power generation has mostly been limited to requirements of ramping up and ramping down (flexible operation) of thermal power units consequent upon addition of renewable energy in the grid. 
There is no work to the best of the knowledge of the author where attempt has been made to find out all the major factors affecting Utilization Factor of thermal power plants from thermal power plant perspective. Also, projection of Utilization Factor for next 05 years could not be found in any published scholarly paper although several newspaper reports have touched this issue.

In essence - there is a need to do comprehensive work to (i) Identify Major factors affecting the Utilization Factors (PLF) of thermal power (ii) Projections of thermal power Utilization Factor (PLF). This research address this gap. (iii) Discuss the outlook on the identified factors

\subsection{Organisation of the paper}

The rest of the paper is organised as follows; Section 3.3 - Objectives of the research Section 3.4- Research Methodology, Section 4- Exploratory Research for Factors Affecting Capacity Utilization of Thermal Power, Section 5- Research Questionnaire, Section 6- Results, Section 7 - Discussion, Section 8 - Conclusion, Section 9- Limitations of the research, Section 10- Figures, Tables and Annexures, Section 11- Author contribution, Section 12- Conflict of Interest, Section 13- References

\subsection{Objectives of the research}

1. To find out the major factors responsible for falling Capacity Utilization (PLF) of thermal power plants in India

2. To find out projected PLF scenario in next 5 years

\subsection{Research Methodology}

\section{Research Design for Research Objective -1}

Objective - To find out the major factors affecting Capacity Utilization (PLF) of thermal power plants in India

\section{Research type}

(1) Exploratory Research through literature survey- Factors were first explored through Literature Review

(2) Exploratory Research through discussion with experts - The domains/areas of concern explored through Literature Review were further discussed with selected experts (10 in total, having work/academic experience of more than 20 years each ) to crystallise to focussed clusters with clearly articulated factors in each cluster which can be tested through a questionnaire.

The above two steps were thought necessary because running a questionnaire without mentioning the factors was not considered a robust way of seeking responses. If we leave the respondents open to just state the factors affecting the PLF of thermal power plant as per respondent's opinion, there was high chance of some important factor being left out either because of a bias, recency effect or simply because of lack of time on the part of respondents. It was therefore thought appropriate to list all the factors (25 Nos) found through the exploratory research and seek opinion on each one of the factors on a Likert scale about the factor having very major, major, neutral, low and very low 
impact on PLF. Quantitative Research through Questionnaire- After the above two exploratory research steps, a questionnaire survey was done for seeking opinion of respondents on a Likert Scale. The questionnaire was administered to a targeted professionals working in the power sector consisting of following -

(i) Executives from power companies in Central Sector

(ii) Executives from power companies in State Sector

(iii) Executives from power companies in Pvt Sector

(iv) Consumers

(iii) Regulators

(iv) Consultants

(v) Academicians

Respondents were experienced professionals in power sector. $75.18 \%$ of the total respondents who replied have more than 20-year experience in the sector. The factors explored through exploratory research are detailed in next section. The others?

Sample Size- 137

Analysis

Hypothesis testing for proportion

(Whether more than $50 \%$ of the experts feel a particular factor has major impact on thermal power PLF)

\section{Research Design for Research Objective -2}

Objective-2- To find out what could be the projected scenario in next 5 (Capacity Utilization i.e. PLF)

Research type

Quantitative Research

Data source and size

Secondary Data

Last 30 Years Data of major factors (quantitative) affecting PLF of thermal power

Analysis Tools

Multiple nonlinear Regression Analysis (Excel) taking all significant factors which affect PLF of thermal power as independent variables and PLF of thermal as dependent variable

\section{Exploratory Research for Factors affecting Thermal Power Capacity Utilization}

Study of the literature pointed out towards following factors which are affecting Capacity Utilization (PLF) of thermal power plants.

- Effect of Renewable Energy

- Low Growth of demand as against projected 
- Overcapacity

- Financial health of Discoms

- Fuel Availability

- Evacuation constraints

- Policy issues discouraging the thermal power generation

These factors were then discussed with experts in the power sector (Senior, experienced professionals working in thermal power sector, senior academicians teaching power related subjects and consultants working in the field of power sector- all of them had more than 25 years' experience in the field). As a result of the discussion, the factors were enhanced and re-categorised in nine major factors. All these heads were broken in sub factors. Finally, total 25 factors responsible for Capacity Utilization (CUF of PLF) were identified through the exploratory research. The result is as below-

\section{Economic / Cost related factors}

1.1) Poor financial health of power procuring companies (Discoms) is forcing them to reduce power procurement even if while demand exists

1.2) The power utilities of state sector (State Gencos ) are in financial distress and are unable to maintain their own power plants in good condition

1.3) The power utilities of private sector (IPPs) are in financial distress and are unable to maintain their own power plants in good condition

1.4) Due to large number of thermal power loans becoming NPA, banks have reduced lending creating fund crunch for power producers 1.5) Generating electricity from coal is no longer attractive business due to rising costs, forcing the thermal generators to cut down generation

\section{Environment Related Factors}

2.1) New emission norms set by Govt in 2015 for thermal power plants

2.2) Society's growing concern about environment is forcing power stations to reduce production

\section{Factors related to mix of power generation sources}

3.1) Disproportionately high share of thermal power in Indian grid (63.7\% of total installed capacity as on 31.03.2019)

3.2) Substantial addition of renewable energy (solar and wind) having must-run status in the grid

\section{Transmission Related Constraints}

4.1) Grid evacuation constraint (line loading limitations) in some areas causing reduction in power generation 


\section{Thermal Power Plant Technical Issues}

5.1) The thermal power plants are experiencing forced outages // technical problems (like boiler tube leakages etc) and are unable to generate to full capacity

5.2) Many thermal power plants in India are ageing and are unable to reach full load capacity

5.3) The thermal power plants were designed as base load (full load) operation whereas the grid conditions today demand flexible operation that coal plants are unable to cope up.

If this is happening as a result of forced outages, is this a cause or effect or both?

\section{Demand and Supply related factors}

6.1) Low growth of power demand in the country as compared to projected is resulting in underutilisation of thermal power

6.2) India has reached a stage of being power surplus (on most days in a year) (is this a problem?)

6.3) Although India is power deficit on totality basis, many regions have actually become power surplus

6.4) Large number of players in power generation is resulting in fierce competition

6.5) After opening up of power sector, many new and inexperienced players jumped without understanding the electricity market

\section{Fuel \& Resource Related Factors}

7.1) Low fuel (coal) availability forcing thermal power generators to reduce power generation

7.2) Poor quality of coal having very high ash is forcing thermal power generators to reduce power generation

\section{Tariff/ Policy related factors}

8.1) The tariff / policies are un-supportive of thermal power generators

8.2) Renewable energy is getting promoted at the cost of thermal generators because thermal plants are supposed to generate when nobody else is able to generate and then back down when others are available

8.3) There is lack of policy clarity on whether and how old thermal power plants are to be retired, which creates a dilemma whether to invest in their R\&M (Repairs and Maintenance)

8.4) The Ultra Mega Power scheme, which was initiated by Govt to facilitate development of large capacity power stations by reallocation of risks, did not bear desired results because of policy issues (projects risks were not addressed properly)

\section{Perception about future of coal based generation}

9.1 ) There is a general perception that coal based thermal power will be entirely phased out in the medium / long run which is inhibiting new and modern technology infusion in thermal plants 


\section{Research Questionnaire}

A survey was then conducted based on the Research Questionnaire which gathered opinion of respondents about the 25 factors identified through exploratory research. The response was asked on Likert Scale for all the 25 factors. The responses were categorised as (i) Very High Impact (ii) High Impact (iii) Neutral/Undecided (iv) Low or very low impact. Questionnaire was prepared using Google Forms. The Questions asked in the Research Questionnaire is appended at Annexure - 1

\section{Results}

\subsection{Results for objective -1}

Response on the was sought on Questions from (Annexure -1) from power professionals from in Central Sector Power Producers (Central PSU), State Sector Power Producers (State PSUs), Private Sector Power Producers (IPPs), Consultants and Academicians. Responses were collected through targeted contact using electronic means (Email/ WhatsApp). Total 137 responses were received from 400 people contacted.

An analysis of the 137 responses is presented here. We have done $\mathrm{z}$ statistic test of proportion to ascertain whether majority of the respondents have chosen a particular factor as having high or very high impact. Given our sample $\mathrm{n}=$ 137 ; Null hypothesis (Ho) population proportion P is 0.5 ( i.e only $50 \%$ respondents believe that this factor is high impact (High and Very High responses) have been clubbed for this count). Alternate hypothesis is that $\mathrm{P}$ is significantly greater than $50 \%$. (99\% confidence level)

$(\mathrm{H} 0, \mathrm{P}=0.5$ i.e. $50 \%$,

Ha, $\mathrm{P}>0.5$, a one tailed test)

$\{\mathrm{Pn}>5$ and $\mathrm{P}(1-\mathrm{P}) \mathrm{n}>5$, both conditions are satisfied to run normal distribution test of proportion. $\}$

A Z critical value approach has been used. At first, the $\mathrm{Z}$ critical value at $99 \%$ confidence level (2.576) has been taken and applied in formula below to find $p$ critical value for our sample size (137). Our approach is that if sample $p$ is greater than $\mathrm{p}$-critical, it can be concluded that the Null Hypothesis is rejected. Following calculation shows how $\mathrm{p}$ critical value has been calculated.

$\mathrm{Z}=(\mathrm{p}-\mathrm{p} 0) / \sqrt{ } \mathrm{p} 0(1-\mathrm{p} 0) / \mathrm{n}$

$2.576=(\mathrm{p}-0.5) / \sqrt{ } 0.5(1-0.5) / 137$

This gives,

$\mathrm{p}=0.61$

The p-cutoff (critical value) comes to 0.61 . This means that if $\mathrm{p}$ is more than 0.61 i.e. if more than $61 \%$ percent respondents (as opposed to greater than $50 \%$, if we were to consider a simple majority approach) say that a particular 
factor has major impact, then we infer that this is majority opinion and is not a mere chance of random response. We can then reject null hypothesis that $\mathrm{p}=0.5$ and decide that there is conclusive evidence of majority opinion about a particular factor having major impact. This analysis has been done for responses against each question. If $67 \%$ or more have opined that a particular factor has High or very High impact, we have shortlisted that factor as having Major Factor.

Table-06

\begin{tabular}{|c|c|c|c|c|c|c|c|}
\hline Question & $\begin{array}{l}\text { Total } \\
\text { Responses } \\
\text { saying very } \\
\text { high or } \\
\text { high impact } \\
\text { (a) }\end{array}$ & $\begin{array}{l}\text { Total } \\
\text { responses } \\
\text { neutral/ } \\
\text { undecided } \\
\text { (b) }\end{array}$ & $\begin{array}{l}\text { Total } \\
\text { responses } \\
\text { low or } \\
\text { very low } \\
\text { impact } \\
\text { (c) }\end{array}$ & $\begin{array}{l}\text { Proportion of } \\
\text { responses who } \\
\text { believe that } \\
\text { this has high or } \\
\text { very high } \\
\text { impact }(\mathrm{a} / 137)\end{array}$ & $\begin{array}{l}\text { Proportion } \\
\text { value } \\
\text { correspondin } \\
\mathrm{g} \text { to } \mathrm{Z} \text { cut off } \\
\text { value of } 2.576 \\
\text { (at } 99 \% \\
\text { confidence } \\
\text { level) }\end{array}$ & $\begin{array}{l}\text { Ho } \\
\text { Accepted/ } \\
\text { Rejected }\end{array}$ & $\begin{array}{l}\text { Major } \\
\text { Factor }\end{array}$ \\
\hline $\begin{array}{l}\text { 1.1)Poor financial } \\
\text { health of power } \\
\text { procuring companies } \\
\text { (Discoms) is forcing } \\
\text { them to reduce power } \\
\text { procurement even if } \\
\text { while demand exists }\end{array}$ & 108 & 13 & 23 & 0.79 & 0.61 & Rejected & Yes \\
\hline $\begin{array}{l}\text { 1.2)The power utilities } \\
\text { of state sector (State } \\
\text { Gencos) are in financial } \\
\text { distress and are unable } \\
\text { to maintain their own } \\
\text { power plants in good } \\
\text { condition }\end{array}$ & 101 & 13 & 23 & 0.74 & 0.61 & Rejected & Yes \\
\hline $\begin{array}{l}\text { 1.3)The power utilities of } \\
\text { private sector (IPPs) are } \\
\text { in financial distress and } \\
\text { are unable to maintain } \\
\text { their own power plants in } \\
\text { good condition }\end{array}$ & 79 & 25 & 33 & 0.56 & 0.61 & $\begin{array}{l}\text { Not } \\
\text { rejected }\end{array}$ & No \\
\hline $\begin{array}{l}\text { 1.4)Due to large number } \\
\text { of thermal power loans } \\
\text { becoming NPA, banks } \\
\text { have reduced lending } \\
\text { creating fund crunch for } \\
\text { power producers }\end{array}$ & 73 & 31 & 33 & 0.53 & 0.61 & $\begin{array}{l}\text { Not } \\
\text { Rejected }\end{array}$ & No \\
\hline
\end{tabular}




\begin{tabular}{|c|c|c|c|c|c|c|c|}
\hline $\begin{array}{l}\text { 1.5)Generating } \\
\text { electricity from coal is } \\
\text { no longer attractive } \\
\text { business due to rising } \\
\text { costs, forcing the } \\
\text { thermal generators to } \\
\text { cut down generation }\end{array}$ & 87 & 20 & 30 & 0.63 & 0.61 & Rejected & Yes \\
\hline $\begin{array}{l}\text { 2.1)New emission norms } \\
\text { set by Govt in } 2015 \text { for } \\
\text { thermal power plants }\end{array}$ & 93 & 16 & 28 & 0.68 & 0.61 & Rejected & Yes \\
\hline $\begin{array}{l}2.2 \text { Society's growing } \\
\text { concern } \\
\text { environment is forcing } \\
\text { power stations to reduce } \\
\text { production }\end{array}$ & 75 & 21 & 41 & 0.55 & 0.61 & $\begin{array}{l}\text { Not } \\
\text { Rejected }\end{array}$ & No \\
\hline $\begin{array}{l}\text { 3.1)Disproportionately } \\
\text { high share of thermal } \\
\text { power in Indian grid } \\
(63.7 \% \text { of total installed } \\
\text { capacity as on } \\
31.03 .2019)\end{array}$ & 70 & 33 & 34 & 0.51 & 0.61 & $\begin{array}{l}\text { Not } \\
\text { Rejected }\end{array}$ & No \\
\hline $\begin{array}{l}\text { 3.2)Substantial addition } \\
\text { of renewable energy } \\
\text { (solar and wind) having } \\
\text { must-run status in the } \\
\text { grid }\end{array}$ & 108 & 13 & 16 & 0.79 & 0.61 & Rejected & Yes \\
\hline $\begin{array}{l}\text { 4.1) Grid evacuation } \\
\text { constraint (line loading } \\
\text { limitations) in some areas } \\
\text { causing reduction in } \\
\text { power generation }\end{array}$ & 60 & 33 & 44 & 0.44 & 0.61 & $\begin{array}{l}\text { Not } \\
\text { Rejected }\end{array}$ & No \\
\hline $\begin{array}{l}\text { 5.1)The thermal power } \\
\text { plants are experiencing } \\
\text { forced outages // } \\
\text { technical problems (like } \\
\text { boiler tube leakages etc) } \\
\text { and are unable to } \\
\text { generate to full capacity }\end{array}$ & 64 & 15 & 58 & 0.47 & 0.61 & $\begin{array}{l}\text { Not } \\
\text { Rejected }\end{array}$ & No \\
\hline $\begin{array}{l}\text { 5.2)Many thermal power } \\
\text { plants in India are ageing } \\
\text { and are unable to reach } \\
\text { full load capacity }\end{array}$ & 77 & 20 & 40 & 0.56 & 0.61 & $\begin{array}{l}\text { Not } \\
\text { Rejected }\end{array}$ & No \\
\hline
\end{tabular}




\begin{tabular}{|c|c|c|c|c|c|c|c|}
\hline $\begin{array}{l}\text { 5.3)The thermal power } \\
\text { plants were designed as } \\
\text { base load (full load) } \\
\text { operation whereas the } \\
\text { grid conditions today } \\
\text { demand flexible } \\
\text { operation that coal } \\
\text { plants are unable to } \\
\text { cope up }\end{array}$ & 102 & 13 & 22 & 0.74 & 0.61 & Rejected & Yes \\
\hline $\begin{array}{l}\text { 6.1) Low growth of } \\
\text { power demand in the } \\
\text { country as compared to } \\
\text { projected is resulting in } \\
\text { underutilisation of } \\
\text { thermal power }\end{array}$ & 102 & 20 & 15 & 0.74 & 0.61 & Rejected & Yes \\
\hline $\begin{array}{l}\text { 6.2) India has reached a } \\
\text { stage of being power } \\
\text { surplus (on most days in } \\
\text { a year) }\end{array}$ & 79 & 25 & 33 & 0.58 & 0.61 & $\begin{array}{l}\text { Not } \\
\text { Rejected }\end{array}$ & No \\
\hline $\begin{array}{l}\text { 6.3) Although India is } \\
\text { power deficit on totality } \\
\text { basis, many regions } \\
\text { have actually become } \\
\text { power surplus }\end{array}$ & 87 & 28 & 22 & 0.63 & 0.61 & Rejected & Yes \\
\hline $\begin{array}{l}\text { 6.4) Large number of } \\
\text { players in power } \\
\text { generation is resulting in } \\
\text { fierce competition }\end{array}$ & 82 & 20 & 35 & 0.60 & 0.61 & $\begin{array}{l}\text { Not } \\
\text { Rejected }\end{array}$ & No \\
\hline $\begin{array}{l}6.5) \text { After opening up of } \\
\text { power sector, many new } \\
\text { and inexperienced } \\
\text { players jumped without } \\
\text { understanding the } \\
\text { electricity market }\end{array}$ & 67 & 29 & 41 & 0.49 & 0.61 & $\begin{array}{l}\text { Not } \\
\text { Rejected }\end{array}$ & No \\
\hline $\begin{array}{lr}\text { 7.1) Low fuel } & \text { (coal) } \\
\text { availability } & \text { forcing } \\
\text { thermal } & \text { power } \\
\text { generators to } & \text { reduce } \\
\text { power generation }\end{array}$ & 94 & 19 & 24 & 0.69 & 0.61 & Rejected & Yes \\
\hline
\end{tabular}




\begin{tabular}{|c|c|c|c|c|c|c|c|}
\hline $\begin{array}{l}\text { 7.2) Poor quality of coal } \\
\text { having very high ash is } \\
\text { forcing thermal power } \\
\text { generators to reduce } \\
\text { power generation }\end{array}$ & 82 & 19 & 36 & 0.60 & 0.61 & $\begin{array}{l}\text { Not } \\
\text { Rejected }\end{array}$ & No \\
\hline $\begin{array}{l}\text { 8.1) The tariff / policies } \\
\text { are un-supportive of } \\
\text { thermal power generators }\end{array}$ & 82 & 22 & 33 & 0.60 & 0.61 & $\begin{array}{l}\text { Not } \\
\text { Rejected }\end{array}$ & No \\
\hline $\begin{array}{l}\text { 8.2) Renewable energy } \\
\text { is getting promoted at } \\
\text { the cost of thermal } \\
\text { generators because } \\
\text { thermal plants are } \\
\text { supposed to generate } \\
\text { when nobody else is } \\
\text { able to generate and } \\
\text { then back down when } \\
\text { others are available }\end{array}$ & 115 & 13 & 9 & 0.84 & 0.61 & Rejected & Yes \\
\hline $\begin{array}{l}\text { 8.3) There is lack of } \\
\text { policy clarity on } \\
\text { whether and how old } \\
\text { thermal power plants } \\
\text { are to be retired, which } \\
\text { creates a dilemma } \\
\text { whether to invest in } \\
\text { their R\&M }\end{array}$ & 89 & 26 & 22 & 0.65 & 0.61 & Rejected & Yes \\
\hline $\begin{array}{l}\text { 8.4) The Ultra Mega } \\
\text { Power scheme did not } \\
\text { bear desired results } \\
\text { because of policy issues } \\
\text { (projects risks were not } \\
\text { addressed properly) }\end{array}$ & 73 & 39 & 25 & 0.53 & 0.61 & $\begin{array}{l}\text { Not } \\
\text { Rejected }\end{array}$ & No \\
\hline $\begin{array}{l}9.1 \text { There is a general } \\
\text { perception that coal based } \\
\text { thermal power will be } \\
\text { entirely phased out in the } \\
\text { medium / long run which } \\
\text { is inhibiting new and } \\
\text { modern technology } \\
\text { infusion in thermal plants }\end{array}$ & 79 & 25 & 33 & 0.58 & 0.61 & $\begin{array}{l}\text { Not } \\
\text { Rejected }\end{array}$ & No \\
\hline
\end{tabular}

Table showing results of the survey. Source - Primary research conducted for this paper 


\subsection{Analysis of Results of Survey (Objective-1)}

Table 06 above shows that there are 10 factors out of the 25 factors which fall under Major Factor's category. They are listed below-

Major factors responsible for falling Capacity Utilization (PLF) of thermal power plants in India as concluded from the Research Questionnaire are as below-

1) Poor financial health of power procuring companies (Discoms) is forcing them to reduce power procurement even if while demand exists

2) The power utilities of state sector (State Gencos) are in financial distress and are unable to maintain their own power plants in good condition

3) Generating electricity from coal is no longer attractive business due to rising costs, forcing the thermal generators to cut down generation

4) New emission norms set by Govt in 2015 for thermal power plants.

5) Substantial addition of renewable energy (solar and wind) having must-run status in the grid

6) The thermal power plants were designed as base load (full load) operation whereas the grid conditions today demand flexible operation that coal plants are unable to cope up

7) Low growth of power demand in the country as compared to projected is resulting in underutilisation of thermal power

8) Although India is power deficit on totality basis, many regions have actually become power surplus

9) Low fuel (coal) availability forcing thermal power generators to reduce power generation

10) Renewable energy is getting promoted at the cost of thermal generators because thermal plants are supposed to generate when nobody else is able to generate and then back down when others are available.

\subsection{Regrouping of the factors}

The above ten factors have been further regrouped together based on their similarity in terms of outlook and remedial actions and thus we arrive at following seven major factors-

1. Poor Financial Health of Power Procuring Entities (DISCOMS)

2. Rising cost making thermal power generation un-attractive

3. New Emission Norms are affecting the thermal power generation

4. High proportion of Renewable Energy in Grid causing thermal plants to run under flexible operation regime

5. Renewable Energy having preferential status as must run causing low scheduling of power from thermal power stations

6. Demand Vs Supply projections and regional disparities in demand and supplies

7. Low Fuel (Coal) Availability 


\subsection{Future Scenario Projection (Objective 2)}

\subsubsection{Regression Data}

Regression was run with the three major factors which affect the Capacity Utilization as independent variable, for which numerical data is available from reliable sources and future data can also be estimated under different scenarios.-These three factors independent variables are (i) Peak Demand (MW) (ii) Installed Capacity Coal\& Lignite MW (iii) Total Renewable Energy Installed Capacity (MW), with Capacity Utilization (PLF) has been taken as the dependent variable.

Total last 35 years' time series data was taken for the regression. The following table (Table 07) presents the data on which regression has been run. Data has been taken from Ministry of Power, Govt of India website and Central Electricity Authority website and Coal India Website.

Table 07

\begin{tabular}{|c|c|c|c|c|}
\hline Year & $\begin{array}{l}\text { Peak Demand (MW) } \\
\text { (a) }\end{array}$ & $\begin{array}{l}\text { Installed Capacity } \\
\text { Coal\& Lignite MW } \\
\text { (b) }\end{array}$ & $\begin{array}{l}\text { Total Renewable Energy } \\
\text { capacity }(\mathrm{MW})(\mathrm{c})\end{array}$ & PLF\% $\%$ \\
\hline $1985-86$ & 28090 & 28809 & 0 & 52.4 \\
\hline $1986-87$ & 30850 & 30394 & 0 & 53.2 \\
\hline $1987-88$ & 31990 & 34237 & 0 & 56.5 \\
\hline $1988-89$ & 36245 & 37943 & 0 & 55.0 \\
\hline $1989-90$ & 40385 & 41510 & 0 & 56.5 \\
\hline $1990-91$ & 44005 & 43379 & 18 & 53.9 \\
\hline 1991-92 & 48055 & 44791 & 32 & 55.3 \\
\hline $1992-93$ & 52805 & 46597 & 79 & 57.1 \\
\hline 1993-94 & 54875 & 49147 & 185 & 61.0 \\
\hline $1994-95$ & 57530 & 52139 & 576 & 60.0 \\
\hline $1995-96$ & 60981 & 53547 & 820 & 63.0 \\
\hline $1996-97$ & 63853 & 54154 & 940 & 64.4 \\
\hline $1997-98$ & 65435 & 55969 & 992 & 64.7 \\
\hline 1998-99 & 67905 & 57483 & 1095 & 64.6 \\
\hline 1999-00 & 72669 & 59187 & 1167 & 67.3 \\
\hline $2000-01$ & 74872 & 60890 & 1407 & 69.0 \\
\hline $2001-02$ & 78441 & 62131 & 1702 & 69.9 \\
\hline $2002-03$ & 81492 & 63800 & 2483 & 72.2 \\
\hline 2003-04 & 84574 & 64955 & 2980 & 72.7 \\
\hline $2004-05$ & 87906 & 66416 & 3812 & 74.8 \\
\hline 2005-06 & 93255 & 68433 & 6191 & 73.6 \\
\hline $2006-07$ & 100715 & 71121 & 7760 & 76.8 \\
\hline $2007-08$ & 108866 & 75002 & 11125 & 78.6 \\
\hline 2008-09 & 109809 & 77649 & 13242 & 77.2 \\
\hline
\end{tabular}




\begin{tabular}{|l|l|l|l|l}
$2009-10$ & 119166 & 84198 & 15521 & 77.5 \\
\hline $2010-11$ & 122287 & 92378 & 18454 & 75.1 \\
\hline $2011-12$ & 130006 & 112022 & 24504 & 73.3 \\
\hline $2012-13$ & 135453 & 130221 & 27542 & 69.9 \\
\hline $2013-14$ & 135918 & 145273 & 31692 & 65.6 \\
\hline $2014-15$ & 148166 & 164636 & 35777 & 64.5 \\
\hline $2015-16$ & 153366 & 185172 & 45924 & 62.3 \\
\hline $2016-17$ & 159542 & 192163 & 57260 & 59.9 \\
\hline $2017-18$ & 164066 & 197171 & 69022 & 60.7 \\
\hline $2018-19$ & 177022 & 200704 & 77641 & 61.1 \\
\hline $2019-20$ & 183804 & 205135 & 86759 & 55.4 \\
\hline
\end{tabular}

35 years data of independent variable Peak Demand, Installed Capacity of Coal and Lignite, Installed Capacity of Renewables and Thermal Power PLF- 1985-86 to 2019-20 - Source Ministry of power (MOP) Govt of India, CEA $[1,2,3,4,5]$

There is no missing data in the set. Since there are three independent variables in our study, we need at least 30 data sets to run regression (Peter's rule of thumb). Here we have taken 35 data sets.

\subsubsection{Regression Analysis}

The regression was first tried with Ordinary Least Square using Excel but we have later shifted to Partial Least Sqaure (PLS) method using R. Reasons for choosing this method of regression method is as below.

The regression was first started with Ordinary Least Squares (using excel software) and the coefficients of independent variables ( Peak Demand MW, Installed Capacity Coal\& Lignite MW \& Total Renewable Energy capacity (MW)) were found out. The R square and adjusted R square values obtained were 0.94 and 0.93 respectively. Regression result is as below (Table 8)

Table 08

\section{SUMMARY OUTPUT}

\begin{tabular}{ll}
\hline \multicolumn{2}{l}{ Regression Statistics } \\
\hline Multiple R & 0.96963 \\
R Square & 0.940182 \\
Adjusted & $\mathrm{R}$ \\
Square & 0.934393 \\
Standard Error & 2.050611 \\
Observations & 35 \\
\hline
\end{tabular}

\begin{tabular}{llllll}
\hline ANOVA & & & & & \\
\hline & & & & & Significance \\
& df & SS & MS & F & F \\
\hline Regression & 3 & 2048.827 & 682.9424 & 162.4117 & $4.86 \mathrm{E}-19$
\end{tabular}




\begin{tabular}{|c|c|c|c|c|c|c|c|c|}
\hline Residual & 31 & 130.3552 & 4.205006 & & & & & \\
\hline Total & 34 & 2179.182 & & & & & & \\
\hline & & Standard & & & & Upper & Lower & Upper \\
\hline & Coefficients & Error & t Stat & P-value & Lower $95 \%$ & $95 \%$ & $95.0 \%$ & $95.0 \%$ \\
\hline Intercept & 46.03528 & 1.357908 & 33.90162 & $4.55 \mathrm{E}-26$ & 43.26581 & 48.80475 & 43.26581 & 48.80475 \\
\hline Peak Demand & & & & & & & & \\
\hline (MW) (a) & 0.000487 & $2.5 \mathrm{E}-05$ & 19.4899 & 5.92E-19 & 0.000436 & 0.000538 & 0.000436 & 0.000538 \\
\hline Installed Capacity & & & & & & & & \\
\hline Coal\& Lignite & & & & & & & & \\
\hline MW (c ) & -0.00024 & $3.45 \mathrm{E}-05$ & -6.94093 & 8.72E-08 & -0.00031 & -0.00017 & -0.00031 & -0.00017 \\
\hline Total Renewable & & & & & & & & \\
\hline Energy capacity & & & & & & & & \\
\hline$(\mathrm{MW})(\mathrm{d})$ & -0.00032 & $5.58 \mathrm{E}-05$ & -5.76887 & $2.37 \mathrm{E}-06$ & -0.00044 & -0.00021 & -0.00044 & -0.00021 \\
\hline
\end{tabular}

Regression results- Source Regression using Excel

From the regression above we get the equation -

PLF $=46.03528+0.000487 *$ Peak Demand $+\mathbf{( - 0 . 0 0 0 2 4 )} *$ Total installed capacity of Coal \& Lignite + (0.00032)* Total installed renewable capacity

$\mathrm{P}$ values of all the intercept and coefficients were very low at 4.55E-26, 5.92E-19, 8.72E-08, 2.37E-06 respectively. $\mathrm{T}-$ Stat values were $33.90162,19.4899,-6.94093$ and -5.76887 respectively. The High t-Stat Value $>2.0$ and Low Pvalue $<0.05$ indicated that there is evidence in favour of all coefficients being significant.

However, when the data set was tested for multicollinearity, it was found that the $\mathrm{X}$ variables had high correlation, despite all the $\mathrm{X}$ variables being individually significant. Since the main aim of this part study is the prediction of PLF\% in the upcoming years and multicollinearity could have been ignored in these circumstances.

Yet, to make the model more robust, it was decided to use Partial Least Square (PLS) method using R. This method helps reduce the number of predictors to a smaller set of uncorrelated components while retaining the impact of all of the variables on Y. The PLS method squares regression-modelling works by attempting to maximise the covariance in orthogonal space between $\mathrm{x}$ scores ( $\mathrm{T}$ components) and $\mathrm{y}$ scores (U components), rather than the variables themselves. Consequently, it does not suffer from the same assumptions concerning data structure as multiple linear regression modelling, and crucially is not invalidated by covariance in predictor variables. It is therefore well suited to time-series data, which is typically characterised by high degrees of covariance amongst predictor variables.

In our PLS model, 2 components were chosen based on RMSEP(Root Mean Square Error of Prediction) criterion where the number of components for which RMSEP was minimized is chosen. The results was verified by using SelectNcomp function in $\mathrm{R}$ which suggests the optimal number of components. 
Results of the regression through PLS using R are given below-

Cross-validated using 10 random segments.

(Intercept) 1 comps 2 comps 3 comps

$\begin{array}{lllll}\mathrm{CV} & 8.123 & 7.641 & 2.315 & 2.373\end{array}$

$\begin{array}{llll}\text { adjCV } & 8.123 \quad 7.775 & 2.294 & 2.347\end{array}$

In the present PLS model, for $\mathrm{k}$ fold cross validation the data is divided into $\mathrm{k}$ equally sized segments, which are usually referred to as folds. Further, $\mathrm{k}$ iterations of training and validation are performed so that for each iteration, one fold of data is removed for validation whilst the remaining k-1 folds are used for training the model. The RMSEP is then the mean prediction error for each fold of data removed during cross validation. Consequently, the numbers of components that give the lowest RMSEP are considered optimal for the model (Salter 2018) [26]

A 10- fold cross validation is most common and is the approach used in this study to select the two-component model. The results of the model are as follows:

Figure- 02

TRAINING: \% variance explained

1 comps 2 comps 3 comps

$\begin{array}{llll}\mathrm{X} & 93.05 \quad 99.46 & 100.00\end{array}$

data\$PLF\%` $10.18 \quad 93.85 \quad 94.02$

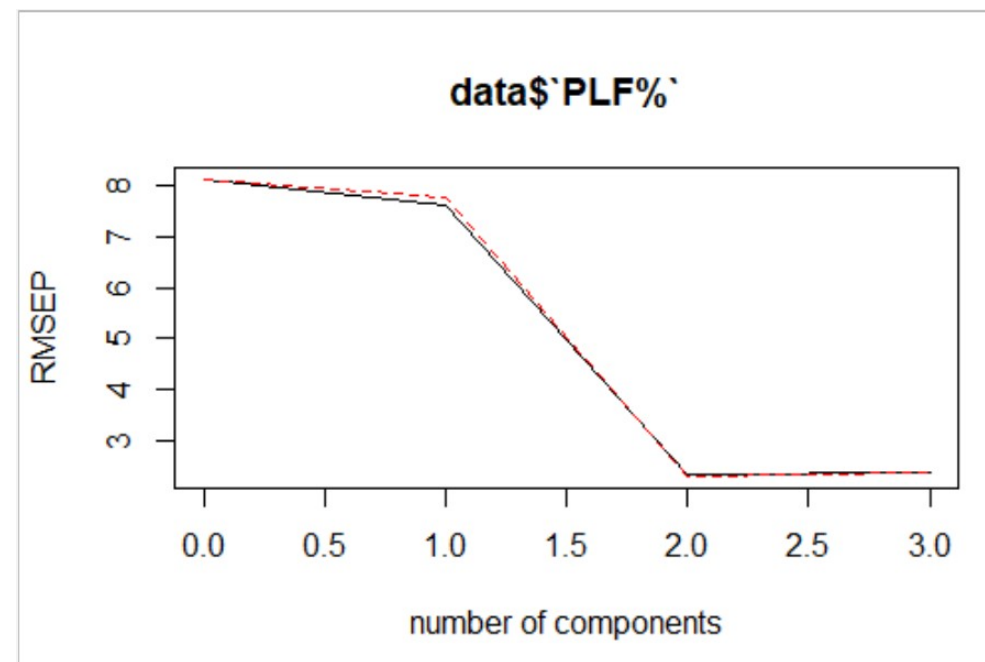

REMSEP minimization chart- Result of analysis

Since RMSEP is getting minimized at 2 components, we use 2 components in the model. As can be observed from the results above, 2 components explain $93.85 \%$ of the variance in the dependent variable, presenting a good fit.

The PLS regression uses latent variables to estimate the value of the dependent variables, hence we do not directly obtain a regression equation. The Jackknife test in the PLS package in R helps us estimate the coefficients and obtain 
a PLS regression equation. In order to obtain the PLS equation, this study uses the jack knife test in R. This test performs approximate $t$ tests of regression coefficients based on Jackknife variance estimates. The original (Tukey) Jackknife variance estimator is defined as $(\mathrm{g}-1) / \mathrm{g} \sum_{-}\{\mathrm{i}=1\}^{\wedge} \mathrm{g}\left(\backslash \mathrm{tilde} \beta \_\{-\mathrm{i}\}-\mid \mathrm{b} \operatorname{br} \beta\right)^{\wedge} 2$, where $\mathrm{g}$ is the number of segments, $\backslash$ tilde $\beta_{-}\{-i\}$ is the estimated coefficient when segment $i$ is left out (called the Jackknife replicates), and $\backslash \mathrm{bar} \beta$ is the mean of the $\backslash$ tilde $\beta \_\{-\mathrm{i}\}$. The most common case is delete-one Jackknife, with $\mathrm{g}=\mathrm{n}$, the number of observations.

Following result (Table 09) is obtained after using Jackknife test.

Table 09

\begin{tabular}{lcc} 
& Estimate & \multicolumn{2}{c}{ Std. Error Df } \\
'Peak Demand (MW) (a)' & $4.9721 \mathrm{e}-04$ & $2.1977 \mathrm{e}-059$ \\
'Installed Capacity Coal\& Lignite MW (c )' & $-2.6945 \mathrm{e}-04$ & $1.7985 \mathrm{e}-059$ \\
'Total Renewable Energy capacity $(\mathrm{MW})(\mathrm{d}){ }^{\prime}$ & $-2.7133 \mathrm{e}-04$ & $5.0504 \mathrm{e}-059$
\end{tabular}

't value $\operatorname{Pr}(>|t|)$

'Peak Demand (MW) (a) $\quad 19.3310 \quad 1.225 \mathrm{e}-08 * * *$

'Installed Capacity Coal\& Lignite MW (c )’ $\quad-10.5141 \quad 2.354 \mathrm{e}-06$ ***

'Total Renewable Energy capacity $(\mathrm{MW})(\mathrm{d}){ }^{\prime} \quad-4.2378 \quad 0.002181 * *$

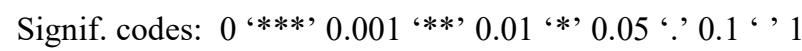

The $\mathrm{t}$ - values are significant and p-values are very small at $99 \%$ confidence level indicating that the model estimates are significant.

PLS Regression Results - Source- Regression using R

\subsubsection{Future PLF Projections - Scenario Building \& What If Analysis}

Using the Partial Least Square (PLS) regression (using R), the Utilization Factor (PLF) has been projected for next five year (i.e. 2020-21 to 2024-25) and five scenarios have been built (i) Scenario- I- Business as Usual (BAU) - Future values of all the three independent variables (refer para 6.4.1) projected as per CAGR of last five years (ii) Scenario- II- Reduced Growth - Coal Based Capacity addition and the Renewable Energy Capacity addition CAGR of each reducing by $3 \%$ (as compared to last 5 years' CAGR) due to slow down of economy and Covid-19 pandemic (RG) (iii) Scenario-III- Low Coal and High Renewable - Growth of Thermal Power Capacity reducing by $5 \%$ and Renewable Power Capacity growth rate increasing by $2 \%$ (LCAR) (iv) Scenario-IVGeneration and Demand Mix suggested by Central Electricity Authority vide Draft report on optimal generation capacity mix for 2029-30 (CEAS) [27] (v) Scenario-V- Generation and Demand Mix suggested by Central Electricity Authority vide Draft report on optimal generation capacity mix for 2029-30 - CEA [27]- Govt of India and assuming that $5000 \mathrm{MW}$ old capacity will be phased out every year. (CEAS+PHOUT).

The national PLF obtained using PLS regression has been bifurcated to Central, State and Private by adding the average historical difference that has been maintained in past between national PLF and these segments (Table-03). 
1) Scenario-I- Business as Usual (BAU) - Future values of all the three independent variables projected as per CAGR of last five years

Table - 10

\begin{tabular}{|l|l|l|l|l|l|l|l|}
\hline Year & $\begin{array}{l}\text { Peak } \\
\text { Demand } \\
\text { (MW) } \\
\text { (a) }\end{array}$ & $\begin{array}{l}\text { Installed } \\
\text { Capacity } \\
\text { Coal\& } \\
\text { Lignite } \\
\text { MW (b) }\end{array}$ & $\begin{array}{l}\text { Total } \\
\text { Renewable } \\
\text { Energy } \\
\text { capacity } \\
\text { (MW)(c) }\end{array}$ & \multicolumn{2}{|l|}{ Projected PLF \% } \\
\hline CAGR & 5.50 & 9.04 & 23.03 & National & Central & State Sector & $\begin{array}{l}\text { Pvt } \\
\text { Sector }\end{array}$ \\
\hline $2020-21$ & 193911 & 223674 & 106742 & 54.06 & 64.15 & 48.51 & 51.93 \\
\hline $2021-22$ & 204574 & 243888 & 131327 & 47.25 & 57.33 & 41.70 & 45.11 \\
\hline $2022-23$ & 215823 & 265928 & 161574 & 38.69 & 48.78 & 33.14 & 36.56 \\
\hline $2023-24$ & 227691 & 289961 & 198788 & 28.02 & 38.11 & 22.47 & 25.89 \\
\hline $2024-25$ & 240211 & 316166 & 244574 & 14.76 & 24.85 & 9.21 & 12.63 \\
\hline
\end{tabular}

Predicted Values Scenario- BAU - Source- PLS Regression Analysis

2) Scenario- II- Reduced Growth (RG) - Peak Demand, Total Installed Capacity, Coal Based Capacity addition and the Renewable Energy Capacity addition CAGR of each reducing by $3 \%$ (as compared to last 5 years' CAGR) due to slow down of economy and Corona

Table 11

\begin{tabular}{|l|l|l|l|l|l|l|l|}
\hline \multirow{2}{*}{ Year } & $\begin{array}{l}\text { Peak } \\
\text { Demand } \\
\text { (MW) } \\
\text { (a) }\end{array}$ & $\begin{array}{l}\text { Installed } \\
\text { Capacity } \\
\text { Coal\& } \\
\text { Lignite } \\
\text { MW (b ) }\end{array}$ & $\begin{array}{l}\text { Total } \\
\text { Renewable } \\
\text { Energy } \\
\text { capacity } \\
\text { (MW)(c) }\end{array}$ & \multicolumn{4}{|l|}{ Projected PLF \% } \\
\hline CAGR & 2.50 & 6.04 & 20.03 & National & Central & State & Pvt r \\
\hline $2020-21$ & 188397 & 217520 & 104139 & 53.68 & 63.77 & 48.13 & 51.55 \\
\hline $2021-22$ & 193105 & 230652 & 125000 & 46.83 & 56.91 & 41.28 & 44.69 \\
\hline $2022-23$ & 197930 & 244577 & 150041 & 38.68 & 48.77 & 33.13 & 36.55 \\
\hline $2023-24$ & 202876 & 259343 & 180097 & 29.01 & 39.09 & 23.45 & 26.87 \\
\hline $2024-25$ & 207946 & 275000 & 216175 & 17.52 & 27.61 & 11.97 & 15.39 \\
\hline
\end{tabular}

Predicted Values - Scenario RG - Source- PLS Regression Analysis 
3) Scenario-III- Low Coal and Aggressive Renewable (LCAR)- Growth of Thermal Power Capacity reducing by $5 \%$ and Renewable Power Capacity growth rate increasing by $2 \%$ (as compared to last 5 years' CAGR)

Table 12

\begin{tabular}{|c|l|l|l|l|l|l|l|}
\hline & Peak & $\begin{array}{l}\text { Installed } \\
\text { Capacity } \\
\text { Year }\end{array}$ & $\begin{array}{l}\text { Demand } \\
\text { Coal\& } \\
\text { (MW) (a) } \\
\text { Lignite } \\
\text { MW (b) } \\
\text { ble } \\
\text { Energy } \\
\text { capacity } \\
\text { (MW) } \\
\text { (c) }\end{array}$ & \multicolumn{2}{|l|}{ Projected PLF \% } \\
\hline CAGR & 5.50 & 4.04 & 25.03 & National & Central & State & Pvt \\
\hline $2020-21$ & 193911 & 213417 & 108477 & 56.36 & 66.44 & 50.80 & 54.22 \\
\hline $2021-22$ & 204574 & 222033 & 135631 & 51.97 & 62.05 & 46.42 & 49.83 \\
\hline $2022-23$ & 215823 & 230997 & 169583 & 45.93 & 56.02 & 40.38 & 43.80 \\
\hline $2023-24$ & 227691 & 240323 & 212033 & 37.80 & 47.89 & 32.25 & 35.67 \\
\hline $2024-25$ & 240211 & 250026 & 265110 & 27.01 & 37.10 & 21.46 & 24.88 \\
\hline
\end{tabular}

Predicted Values Scenario - LCAR - Source- PLS Regression Analysis

4) Scenario IV- CEA Projection (CEAS)- Based on Fuel Mix suggested by Central Electricity Authority vide Draft report on optimal generation capacity mix for 2029-30- CEA- Govt of India)

Table - 13

\begin{tabular}{|c|l|l|l|l|l|l|l|}
\hline \multirow{2}{*}{ Year } & $\begin{array}{l}\text { Peak } \\
\text { Demand } \\
\text { (MW) } \\
\text { (a) }\end{array}$ & $\begin{array}{l}\text { Installed } \\
\text { Capacity } \\
\text { Coal\& } \\
\text { Lignite } \\
\text { MW (b) }\end{array}$ & $\begin{array}{l}\text { Total } \\
\text { Renewable } \\
\text { Energy } \\
\text { capacity } \\
\text { (MW)(c) }\end{array}$ & \multicolumn{2}{|l|}{ Projected PLF \% } \\
\hline CAGR & 6.44 & 2.66 & 17.90 & National & Central & State & Private \\
\hline $2020-21$ & 193913 & 210592 & 102289 & 58.80 & 68.88 & 53.25 & 56.66 \\
\hline $2021-22$ & 225751 & 216193 & 120599 & 68.15 & 78.24 & 62.60 & 66.02 \\
\hline $2022-23$ & 238167 & 221944 & 142186 & 66.92 & 77.00 & 61.36 & 64.78 \\
\hline $2023-24$ & 251267 & 227848 & 167637 & 64.93 & 75.02 & 59.38 & 62.80 \\
\hline $2024-25$ & 265086 & 233909 & 197644 & 62.03 & 72.12 & 56.48 & 59.90 \\
\hline
\end{tabular}

Predicted Values Scenario - CEAS- Source- PLS Regression Analysis 
5) Scenario-V- CEA based Projection and phasing out of old capacity (CEA+PHOUT) Based on Generation and Demand Mix suggested by Central Electricity Authority vide Draft report on optimal generation capacity mix for 2029-30- CEA- Govt of India and assuming that $5000 \mathrm{MW}$ old capacity will be phased out every year. $(C E A S+P H O U T)$

Table 14

\begin{tabular}{|c|c|c|c|c|c|c|c|}
\hline Year & $\begin{array}{l}\text { Peak } \\
\text { Demand } \\
\text { (MW) } \\
\text { (a) }\end{array}$ & $\begin{array}{l}\text { Installed } \\
\text { Capacity Coal\& } \\
\text { Lignite MW } \\
\text { with } 5000 \text { MW } \\
\text { capacity being } \\
\text { phased out every } \\
\text { year (b) }\end{array}$ & $\begin{array}{l}\text { Total } \\
\text { Renewable } \\
\text { Energy } \\
\text { capacity } \\
(\mathrm{MW})(\mathrm{c})\end{array}$ & \multicolumn{4}{|c|}{ Projected PLF \% } \\
\hline CAGR & 6.44 & $\begin{array}{l}2.66 \text { (with } 5000 \\
\text { decommissioned } \\
\text { every year) }\end{array}$ & 17.90 & National & Central & State & Private \\
\hline $2020-21$ & 193913 & 210592 & 102289 & 60.14 & 70.23 & 54.59 & 58.01 \\
\hline $2021-22$ & 225751 & 216193 & 120599 & 70.84 & 80.93 & 65.29 & 68.71 \\
\hline $2022-23$ & 238167 & 221944 & 142186 & 70.96 & 81.04 & 65.41 & 68.82 \\
\hline $2023-24$ & 251267 & 227848 & 167637 & 70.32 & 80.41 & 64.77 & 68.19 \\
\hline $2024-25$ & 265086 & 233909 & 197644 & 68.77 & 78.85 & 63.21 & 66.63 \\
\hline
\end{tabular}

Predicted Values Scenario - CEAS + PHOUT- Source- PLS Regression Analysis

\section{Discussion}

Out of the total 25 factors identified through survey of literature and discussion with experts, our primary research identifies seven major factors affecting Capacity Utilization (PLF) of thermal power plants in India. We have then run the multivariate PLS regression. Here we discuss the results of the regression, projected values of PLF and outlook on all the seven factors identified and indicate remedial measures on controllable factors needing immediate attention.

The seven identified major factors are as below-

1. Poor Financial Health of Power Procuring Entities (DISCOMS)

2. Rising cost making thermal power generation un-attractive

3. New Emission Norms are affecting the thermal power generation

4. High proportion of Renewable Energy in Grid causing thermal plants to run under flexible operation regime

5. Renewable Energy having preferential status as must run causing low scheduling of power from thermal power stations

6. Low Fuel (Coal) Availability

7. Demand Vs Supply projections and regional disparities in demand and supplies 


\subsubsection{Discussion on the scenario projections -}

Multivariate Regression using Partial Least Square (PLS) method using R, with thee relevant major factors ((i) Peak Demand (MW) (ii) Installed Capacity Coal\& Lignite MW (iii) Total Renewable Energy Installed Capacity (MW)) as independent variables and Capacity Utilization (PLF) as independent variable has been run. Thereafter five scenarios have been projected as below.

Scenario -I - Business as Usual (BAU) - Future values of all the three independent variables (Peak Demand, Total Installed Capacity, Coal Based Capacity addition and the Renewable Energy Capacity addition) projected as per CAGR of last five years and Scenario- II- Reduced Growth (RG) - Peak Demand, Total Installed Capacity, Coal Based Capacity addition and the Renewable Energy Capacity addition CAGR of each reducing by $3 \%$ (as compared to last 5 years' CAGR) due to slow down of economy and Corona

In both scenario I \&II (BAU and RG) the PLF drops to as low as $38.6 \%$ by $2022-23$ itself. This is worrying situation and indicates that in Business as Usual (BAU) or Reduced Growth (RG) scenarios the thermal power plants may face crisis as early as 2022-23.

In 2022-23, in Scenario -I (BAU), the Central sector plants will be doing marginally better in 2022-23 at $48.78 \%$. The state and private sector will be in much worse situation reaching $33.14 \%$ and $36.56 \%$ respectively.

By 2024-25, in Scenario- I, BAU, national PLF will reach abysmally low to $14.76 \%$. Central, state and private sector will touch $24.85 \%, 9.21 \%$ and $12.63 \%$ respectively.

In Scenario II-(RG), by 2024-25, national PLF will reach $17.52 \%$, Central, state and private sector will touch $27.61 \%, \quad 11.97 \%$ and $15.39 \%$ respectively.

Scenario-III- Low Coal and Aggressive Renewable (LCAR) - Growth of Thermal Power Capacity reducing by $5 \%$ and Renewable Power Capacity growth rate increasing by $2 \%$ (as compared to last 5 years' CAGR) In this scenario the PLF drops at a reduced rate. National average PLF is projected at $27.01 \%$ in 2024-25. Central sector will maintain $37.10 \%$ PLF and state and private sector will maintain $21.46 \%$ and $24.88 \%$ respectively.

All the above three scenarios show a grim picture. It is pertinent to note that lower PLF not only results in underutilisation of costly assets, it also means that the high efficiency new supercritical power plants will not be running at their design efficiencies and would rather run at suboptimal, subcritical condition, defeating the purpose of setting up new high efficiency units.

Scenario IV-CEAS - Based on Generation and Demand Mix suggested by Central Electricity Authority vide Draft report on optimal generation capacity mix for 2029-30- CEA- Govt of India. This scenario depicts a much 
encouraging picture for thermal power stations. The scenario is projected considering coal capacity addition rate decelerated considerably to about $2.66 \%$ CAGR against current (BAU) $6.04 \%$, Peak demand increase projected steeper at 6.44 as compared to current CAGR of $5.5 \%$ (BAU) and Renewable Energy addition CAGR reduced to $17.90 \%$ from current $23.03 \%$ (BAU).

A combined effect of all three independent variable following this path makes the national PLF to increase to $58.80 \%$ in the year 2020-21 itself. An interesting result is observed here. The PLF rises to $68.15 \%$ in the next year i.e. in 2021-22. This effect appears to be occurring because the PLF might recover fast correcting the corona dip last year, riding over rising demand and supported by slowing down of new thermal capacity addition. Under this scenario, by 2024-25 - the PLF reaches $62.03 \%$. (Central, state and private sector are projected to operate at $72.12 \%, 56.48 \%$ and $59.90 \%$ respectively.

Scenario-V-CEAS+PHOUT - - Based on Generation and Demand Mix suggested by Central Electricity Authority vide Draft report on optimal generation capacity mix for 2029-30- CEA- Govt of India and assuming that $5000 \mathrm{MW}$ old capacity will be phased out every year. (CEAS+PHOUT). Here it is assumed that over and above the demand and generation mix projections of CEA, about $5000 \mathrm{MW}$ of old, inefficient thermal capacity is phased out every year.

By far this scenario appears to be most optimum from the thermal power perspective. In this case national PLF sustains at $68.77 \%$ by 2014-25. Central, state and private sector are projected to operate at $78.85 \%, 63.21 \%$ and $66.63 \%$ respectively. This is the scenario where all the three segments (Central, state and private) appear to be maintaining a reasonably high (above $60 \%$ ) PLF in next five years.

\subsection{What if Analysis}

The Jack-knife test has been used to find out the estimates of the three independent variables ( table 09). Using the estimates given by this method it is found that if peak demand increases by $5000 \mathrm{MW}$, the PLF will increase by $2.4 \%$ (4.9721e-04* 5000). If Installed Capacity of coal and lignite increases by $5000 \mathrm{MW}$, the PLF will decrease by 1.35 $\%(-2.6945 \mathrm{e}-04 * 5000)$ and if total renewable energy capacity increases by $5000 \mathrm{MW}$, the PLF will decrease by 1.36 $\%$ (-2.7133e-04*5000). (Taking 2019-20 as base year)

The highest impact is of peak demand (MW) in the positive direction $+2.4 \% / 5000 \mathrm{MW}$, followed by total renewable energy (MW) in the negative direction (-) 1.36\%/5000 MW and then by that of installed capacity of coal and lignite (MW) again in the negative direction i.e. (-) $1.35 \% / 5000 \mathrm{MW}$. 


\subsection{Discussion and Outlook on all the Major Factors affecting Utilization Factor (PLF) of thermal power plants.}

Here we discuss the outlook on all the seven identified major factors (Ref Para 7) affecting the Utilization Factor (PLF) of thermal power stations.

\subsubsection{Poor Financial Health of Power Procuring Entities (DISCOMS)- State distribution} companies or Discoms, responsible for delivering electricity to households, industries and commercial establishments - are struggling with high AT \& C losses, are burdened with very high debt, and are facing huge losses. One of the major reasons behind power sector agony in India is the inability of Discoms to purchase and distribute electricity efficiently. Losses and thefts in transmission and distribution and non-recovery of bills are some issues which the distribution is facing. This is reflected in Discoms' Aggregate Technical and Commercial losses (AT\&C losses). Although the losses have decreased over the years at $20 \%$ now but they remains well above the UDAY-mandated target of $15 \%$ to be achieved by March 2019. UDAY stands for Ujjwal Discom Assurance Yojana, a Govt of India scheme to reform the distribution sector. (Sneha Alexander, The Mint, 2020, March 18) [28]

Most Discoms have high gap between Average Revenue Realized and Average Cost of Supply (ARR-ACS gap) per unit of electricity sold. The high ARR-ACS gap means that electricity is being sold at lesser rate than what it is bought at. This is a reason of increasing operating losses. Power supply tariff is indirectly controlled by the State Govts (even while there are State Regulators, SERCs in each state). These losses of Discoms have important bearing on the power supply chain. Payments from Discoms to power generation companies are getting increasingly delayed which in turn is creating stressed assets in generation sector.

Bloomberg Quint (2020, April 20) [29] reported that thanks to regulated prices and the general mismanagement of the network, India's distribution companies (known as Discoms) lose around 360 rupees (\$4.63) on every megawatt-hour of electricity they deliver - equivalent to roughly $10 \%$ of the retail price. If we spread that value across a market generating more than 1.5 billion megawatt hours a year, the losses quickly mount up. Total debt in the sector now amounts to 4.3 trillion rupees ( $\$ 56.4$ billion), according to a recent report by the Asian Development Bank Institute. Gopal K. Sarangi, Arabinda Mishra, and Farhad Taghizadeh-Hesary (2019) [30]

For improving the poor financial health of Discoms, Govt of India has come up with a comprehensive UDAY scheme. Brought in 2016, this scheme envisages cleaning the debt ridden balance sheets of the Discoms by taking over the debt by respective state Governments, absorbing some of the losses by the State Governments and parallely reduction of AT\&C losses by Discoms through several technical and commercial interventions.

While there has been reduction in AT\&C Losses they continue to incur huge losses. Discoms' financial losses stood at Rs 28,369 crore at the end of FY19, up 88.6\% year-on-year reports: Anupam Chatterjee, Financial Express (2019, July 30) [31] 
The financial position of Discoms still therefore remains a matter of worry. This situation is likely to continue till further reforms are taken in the distribution sector and there is a very strong social and political will to make the Discoms profitable.

Discoms must be strengthened and made professional. There is need for training of staff and consumers, infusion of IT based management, automated billing and payment platforms and bringing transparency and accountability at all levels. UDAY scheme should be monitored and implemented in letter and spirit. A separate regulator for Distribution sector will also help in recovery of the system. Sector is already open to private participation. More territories should be opened up for private participation.

7.3.2 Rising Costs making thermal power generation un-attractive - The regular inflation and increase in wages of employees and workers is something which is already affecting the O\&M cost of thermal power which is manpower intensive industry. Moreover, the major input to thermal power - coal is also becoming costlier. Following table shows the Wholesale Price Index (Non coking coal) for last seven years.

Table -15

\begin{tabular}{|l|l|}
\hline Financial Year & Index \\
\hline $\mathbf{2 0 1 8 - 1 9}$ & 119 \\
\hline $\mathbf{2 0 1 7 - 1 8}$ & 112.5 \\
\hline $\mathbf{2 0 1 6 - 1 7}$ & 110.5 \\
\hline $\mathbf{2 0 1 5 - 1 6}$ & 109.6 \\
\hline $\mathbf{2 0 1 4 - 1 5}$ & 109.6 \\
\hline $\mathbf{2 0 1 3 - 1 4}$ & 106.8 \\
\hline $\mathbf{2 0 1 2 - 1 3}$ & 103.2 \\
\hline
\end{tabular}

Wholesale Price Index (Non coking coal), Source - (Office of the economic advisor of India https://www.eaindustry.nic.in/display data_201112.asp) [32]

Coal is also facing headwinds due to various other reasons. It is now largely perceived a bad guy all over the world due to the gaseous emission and ash that it produces. More and more pressure to reduce environment footprint is necessitating addition of pollution control equipment. Moreover, Govt has introduced special levy on coal prices. The coal cess, based on the principle of polluter pays, was introduced in 2010 and levied on domestic and imported coal. The cess has risen from Rs 50 per tonne in 2010 to Rs 200 per tonne in 2015 and to `400 per tonne in 2016. Future of India's Green Fund from Coal- the Economic Times (2019, Dec 26) [33]. These additional capital as well O\&M cost are adding to the woes of thermal power generators. Clyde Russell, Reuters, 2019, Feb 20 [34] reported that the main reason coal may have to face battle to fuel India's future energy needs is that it's simply becoming too expensive relative to renewable energy alternatives such as wind and solar. In recent months, power supply auctions have shown that renewables can be offered at less than 3 rupees (4 U.S. cents) per kilowatt hour, a tariff that coal-fired generators have difficulty matching. There is also zero chance that new coal generators can produce electricity at rates competitive to renewables, given higher capital and operating costs.

We argue that this situation is likely to continue and coal is likely to face even more costs thus creating further pressures on PLF. 
7.3.3 New Emission Norms- The environment ministry had issued a notification on December 7, 2015 setting air pollution standards for thermal power plants. (CEA Report [35], FICCI Report [36] ). These norms as below have been fixed particularly w.r.t. particulate matter, SOx, NOx, Mercury and Liquid Discharge.

\begin{tabular}{|c|c|c|c|c|c|}
\hline $\mathbf{M g} / \mathbf{N m}^{3}$ & Plant Size & $\begin{array}{l}\text { Existing (prior) } \\
\text { Standards }\end{array}$ & $\begin{array}{l}\text { Installed before } \\
31^{\text {st }} \text { Dec'03 }\end{array}$ & $\begin{array}{l}\text { Installed between } \\
1^{\text {st }}{\text { Jan'04 to } 31^{\text {st }}} \\
\text { Dec'16 }\end{array}$ & $\begin{array}{l}\text { Installed after } 1^{\text {st }} \\
\text { Jan'17 }\end{array}$ \\
\hline $\mathrm{PM}$ & All & $150-350$ & 100 & 50 & 30 \\
\hline \multirow[t]{2}{*}{$\mathrm{SO}_{2}$} & $<500 \mathrm{MW}$ & None & 600 & 600 & 100 \\
\hline & $>500 \mathrm{MW}$ & None & 200 & 200 & 100 \\
\hline $\mathrm{NO}_{\mathrm{x}}$ & All & None & 600 & 300 & 100 \\
\hline $\mathrm{Hg}$ & All & None & $0.03(>500 \mathrm{MW})$ & 0.03 & 0.03 \\
\hline
\end{tabular}

Water Consumption Norms

(i) All Plants with Once through cooling (OTC) shall install Cooling Tower (CT) and achieve specific water consumption of $3.5 \mathrm{~m} 3 / \mathrm{MWh}$.

(ii) All existing CT Plants must reduce specific water consumption upto $3.5 \mathrm{~m} 3 / \mathrm{MWh}$.

(iii) All plants installed after 1st Jan'17 must achieve maximum specific water consumption upto $2.5 \mathrm{~m}^{3} / \mathrm{MWh}$ and achieve zero waste water discharge.

These are stiff norms are comparable to strict world standards. Further to this, India has made strong commitments to the world body (UNFCCC) through its Nationally Determined Contributions (NDCs) to reduce Global Warming. India has pledged to improve the emissions intensity of its GDP by 33 to 35 per cent by 2030 below 2005 levels. It has also pledged to increase the share of non-fossil fuels-based electricity to 40 per cent by 2030 . These commitments mean long term policy support to renewable energy and restricting coal based generation. (India's NDCs, UNFCCC) [37]

Muhammad Tabish Parray and Rahul Tongia, Brookings- (2019, August 28) [38] write that one big unknown for thermal power plants is compliance with the environmental norms, which will result in downtime for retrofitting existing coal plants, or even retirement of some older capacity. Almost all the planned upgradation of the power plants to meet upcoming environmental requirements is scheduled in 2021-2022. This will lead to many power plants being shut down simultaneously during that period.

With rising concern about pollution, it is felt that the challenges for thermal generators on environment front are likely to remain or be even more stringent. The PLFs projected in this study can be even further negatively affected due to the stringent environmental conditions.

\subsubsection{High proportion of Renewable Energy in Grid causing thermal plants to run under flexible operation regime + Renewable Energy having preferential status as "must run" causing low scheduling of power from thermal power stations}

Renewable energy, particularly Solar and Wind are time dependent (times when sun shine or wind is available). This means that renewable energy would not be available in the grid on 24x7 basis (unless the power storage technologies become competitive and cost of renewable power generated, stored and retrieved through renewable + storage 
combination becomes affordable). As discussed earlier in the paper, whenever renewable energy is available in the grid, the thermal power is not scheduled to the extent renewable meets the demand. The buying entities (Discoms) are under obligation to buy from renewable sources under a provision called renewable purchase obligation (RPO). Financial Express, (2018, June 16) [8] reported that Indian government has raised the minimum quantity of renewable power that states must procure to $21 \%$ of their overall power purchases by FY22. It is pertinent to add here that this RPO obligation is terms of energy (kWh) and not in terms of power (MW). The implication is that since the renewable energy is not available round the clock, the purchasing entities (Discoms) have to buy higher percentage in terms of MW whenever renewable energy is available. This could be as high as $50-60 \%$ in MW terms. When such large quantum is bought from renewables, thermal has to reduce generation (ramp down). At other times in a day, when renewable is not available (say in the evening peak time), then thermal power will have to ramp up generation to meet the demand. This situation forces thermal power plants to run a cyclic operation or flexible operation regime where they have to ramp up ramp down generation several time a day. This situation will continue and will become even more stringent. The Economic Times (2019, Oct 06) [39] reported that the Delhi's power regulator DERC has imposed penalties to the tune of Rs 1.71 crore on Discom Tata Power Delhi Distribution Limited (TPDDL) and Rs 2.88 crore each on BSES Yamuna Power Limited (BYPL) and BSES Rajdhani Power Limited. BRPL for defaulting on renewable energy purchase obligations (RPO) for three financial years. The Delhi Electricity Regulatory Commission (DERC) in its order last month found default on the part of the three power Discoms in meeting their RPO.

Caused due to integration of renewable energy, such cyclic loading creates several challenges for the thermal power generator. These plants were not designed to run under such flexible regime. The stability of boiler flame gets endangeroured at lower loads. The turbine also faces difficulty of varying main steam pressure and temperature. Moreover, all the metal parts and welded joints undergo creep and fatigue. This is a new challenge for operation and maintenance of the power plants. The plants are supposed to respond fast and maintain the ramp rate as required for grid stability. The Central regulator Central Electricity Regulatory Commission (CERC) has come up with tariff regulation 2020-24 wherein it has stipulated that in case of a thermal generating station, with effect from 1.4.2020: a) rate of return on equity shall be reduced by $0.25 \%$ in case of failure to achieve the ramp rate of $1 \%$ per minute; b) an additional rate of return on equity of $0.25 \%$ shall be allowed for every incremental ramp rate of $1 \%$ per minute achieved over and above the ramp rate of $1 \%$ per minute, subject to ceiling of additional rate of return on equity of $1.00 \%$. [40]

Faced with this new situation, thermal power plants are bracing themselves for flexible operation. This requires major changes in maintenance strategy and operation strategy. It will also require investment in retrofitting some equipment with additional functionality and monitoring. If such changes are not done, power plant units will either trip on fault or will have to be put under shutdown. This will result in further fall of plant Utilization Factor (PLF). It means that while PLFs will be down due to ramp down situation, it can go drastically down if the plants do not cope up with flexible operation because in that case they will have to be shut down. 
This is one area where urgent action is required. Thermal power producers must invest and train people to run plants on flexible operation. All original equipment manufacturers should also support the power producers tiding over this critical challenge. Since this will add additional burden on already stressed thermal sector, flexibilization should be incentivised through a separate kind of green investment fund. In a way, by being flexible, thermal is actually supporting the renewable generation in the grid. When renewable is available thermal backs down to let renewable be scheduled and when renewable goes out, thermal kicks in again. Thermal is thus acting as an ancillary to renewable. In such situation thermal is actually helping renewables, without being remunerated for this service. A green investment fund or some such fund may be created through tax or other measures and the thermal sector may be supported for participating in the flexibiliztaion through special incentive on per unit of electricity generated basis.

7.3.6 Availability of fuel -As brought out earlier in the report, PLFs of plants have suffered due to low fuel availability. The following table gives the coal production in India in MMT from 1985-86 to 2019-20. The future projection of five years of coal production has also been done considering the last five year CAGR of $2.66 \%$ ( 2015 16 to 2019-20)

\begin{tabular}{|c|c|c|c|}
\hline Year & $\begin{array}{l}\text { Actual coal production statistics (MMT) } \\
\text { (e) }\end{array}$ & Year & $\begin{array}{c}\text { Projected Production assuming } 2.66 \\
\% \quad \text { historical CAGR of } \\
(2015-16 \text { to } 2019-20)\end{array}$ \\
\hline $1985-86$ & 77.85 & $2020-21$ & 740 \\
\hline $1986-87$ & 85.34 & $2021-22$ & 782 \\
\hline $1987-88$ & 90.28 & $2022-23$ & 825 \\
\hline $1988-89$ & 98.66 & $2023-24$ & 871 \\
\hline $1989-90$ & 106.29 & $2024-25$ & 871 \\
\hline $1990-91$ & 113.66 & & \\
\hline $1991-92$ & 119.96 & & \\
\hline $1992-93$ & 123.94 & & \\
\hline $1993-94$ & 126.06 & & \\
\hline $1994-95$ & 133.10 & & \\
\hline $1995-96$ & 142.64 & & \\
\hline $1996-97$ & 147.37 & & \\
\hline $1997-98$ & 146.47 & & \\
\hline 1998-99 & 143.27 & & \\
\hline 1999-00 & 152.30 & & \\
\hline $2000-01$ & 154.24 & & \\
\hline $2001-02$ & 161.07 & & \\
\hline $2002-03$ & 168.08 & & \\
\hline 2003-04 & 181.61 & & \\
\hline $2004-05$ & 382.62 & & \\
\hline $2005-06$ & 407.04 & & \\
\hline $2006-07$ & 430.83 & & \\
\hline
\end{tabular}




\begin{tabular}{|c|c|l|l|}
\hline $2007-08$ & 457.08 & & \\
\hline $2008-09$ & 492.75 & & \\
\hline $2009-10$ & 532.04 & & \\
\hline $2010-11$ & 532.69 & & \\
\hline $2011-12$ & 539.95 & & \\
\hline $2012-13$ & 556.4 & & \\
\hline $2013-14$ & 565.77 & & \\
\hline $2014-15$ & 609.18 & & \\
\hline $2015-16$ & 639.23 & & \\
\hline $2016-17$ & 657.87 & & \\
\hline $2017-18$ & 675.4 & & \\
\hline $2018-19$ & 730.35 & & \\
\hline $2019-20$ & 701 & & \\
\hline CAGR of Last Five & 2.66 & & \\
\hline Years & & & \\
\hline
\end{tabular}

This projection shows that production will reach 871 MMT by 2024-25. The State-run Coal India (The largest and the monopoly coal producer in India) has set itself an annual production target of 1 billion tonnes till 2024 - Ankit Saproo, Economic Times, (2020, Jan 02) [41]. Further, the Govt is planning to auction over 200 coal blocks in the next five years. The move is in accordance with Govt's efforts to lower India's dependence on coal imports. Removing hurdles in commercial coal mining will help in making India self-sufficient in coal production to meet the requirements.

Here we consider the Scenario V (Table 14), in which coal power installed capacity rises at a slow rate of CAGR of $2.66 \%$, and $5000 \mathrm{MW}$ worth old capacity is phased out every year. In this situation if the coal production rises at $2.66 \%$ CAGR (Which is the minimum rate at which coal production capacity is expected to rise), and commercial mining is started in the auctioned mines as planned by the Govt, the coal production is expected to cover the coal requirement of the thermal power stations in the country and any coal shortage may not be affecting coal based generation

\subsubsection{Demand Vs Supply projections and regional disparities in demand and supplies}

Data from Govt of India, Ministry of Power indicates that India has energy shortage at national level. In 2019-20 energy shortage was $0.7 \%$ and peak shortage was $0.5 \%$. (Ministry of Power (MoP) 2020) [3]. Prima facie this means that all the power available in the country should be scheduled/purchased unless there are factors affecting the purchase. As it comes out, one of the underlying issue is slower growth of demand against expected. Bilal Abdi \& Anshul Joshi, The ET Energy World (2020 Jan 03) [42] reported that the country's peak demand for power, a proxy for industrial activity, stood at 183,804 MW in the first seven months of the current financial year (2019-20), growing at a dismal 3.83 per cent, lowest in the period since financial year 2017-2018. In November, too, peak power demand fell 4 per cent to 155,928 Mega Watt (MW) as compared to the same month last year. The country's Energy Demand slowed to 2 per cent to 785,488 million units (MU) in the first seven months of the current financial year, lowest growth recorded in the period since financial year 2014-2015. 
Bloomberg Quint (2020, April 20) [29] reported that over the five years through 2018, India added output equivalent to 50 nuclear power stations, accounting for $13 \%$ of the increase in generation worldwide (China, where almost all of the power industry is state-controlled, made up 53\%). That booming market hasn't translated into good times for the industry. Out of 45 Indian electricity companies for which Bloomberg studied it said that, just two are covering their cost of capital. As per the report the Load factors have been falling for years thanks to an overzealous build-out of coal plants in the early 2010s. These generators struggle to make money when load factors fall much below $70 \%$; were running at just 56\% said the report when it was published on April 04 2020. With reports that power demand is down by as much as a quarter due to the Covid-19 shutdown, they'll do well to be much above $40 \%$ at the moment, the report further added.

Muhammad Tabish Parray and Rahul Tongia, Brookings- (2019, August 28) [38] write that for the first time, India has sufficient or even surplus electricity generation capacity. Headline numbers show India's gross installed electricity capacity is over $350 \mathrm{GW}$, but the maximum load met has been approximately $180 \mathrm{GW}$. A significant fraction of this gap between demand and supply is explained by grid-level losses (even before distribution) losses, infirm capacity (Renewable Energy, or RE), as well as plants under "outages", which span both technical outages as well as lack of demand, lack of fuel, etc. Examining all the outages across all plants, we find that the "recoverable surplus" is only about $30 \mathrm{GW}$. This assumes fuel adequacy, as well as willingness by Discoms to buy such power.

The above situation means that if there are no grid evacuation constraints, fuel is available at the plants and Dicoms have financial ability to buy, and power can be sold by any producer anywhere and can be bought by anybody anywhere, we have a surplus of about $30 \mathrm{GW}$ on the national level. However, this "surplus" remains a notional surplus. Since most of the power is sold in the country through long term Power Purchase Agreements, the power producer and the buyer are tied up through the agreement. The buyer, typically a Discom, pays the fixed charges to the power producer irrespective of whether it offtakes power or not ( subject to the generation asset being available to generate, typically denoted by Declared Capability of the power plant. The purchaser then pays separately for the energy charges (variable charges) as per actual energy scheduled. In a situation, when a purchasing entity (Discom) has several sources to buy power from and also has to meet RPO, it may not buy all the available power from a particular producer. Since the purchaser pays the full fixed charges, it has the right to buy or keep the asset available for buying as the need arises for the purchaser. So the producer is asked to ramp down generation. At the same time, elsewhere in the country, there could be a buyer, who is ready to buy power at the rate which the producer is giving to the contracted buyer or even at a higher price. In absence of a techno commercial mechanism this exchange was not feasible.

A new regulation called Real Time Market (RTM) has come a breather in this situation. Under this mechanism, in the event of the power producer not getting full dispatch schedule from contracted buyer, the power producer takes prepermission of the buyer to sell the additional quantum of electricity in open market through trading in electricity stock exchange. The stock exchange connects buyers and sellers through price clearing mechanism in real time in short cycles. The electricity can thus get sold to a willing buyer. Any additional gain made by power producer in the variable cost, will be shared between the power producer and the original contracted buyer (because the original 
contracted buyer pays for the fixed charges of the power producer and it the right to reserve the capacity for its own use in case of need By foregoing its right, the buyer is sacrificing the reserve capacity.

It is suggested that RTM process should be made simpler, top of the line software with $24 x 7$ backend support should be put in place. All the concerned staff, both at power producer and the purchaser end, should be fully trained on the process and software.

Another very pertinent action emerges here from this research. The capacity addition plans and demand forecasting require urgent attention. The study shows that further capacity in thermal should be done with lot of caution. The business as usual (BAU) scenario will result in average national PLF touching below $14.75 \%$ as early as 2024-25 (Table 10). The CEA's suggested draft future generation mix appears to be in the right direction. Under this, the thermal capacity addition is slowed down to around $2.66 \%$ against the current five year CAGR of $9.04 \%$ (Table 13), Scenario CEAS. This brake will help recover the PLF of newly established high efficiency thermal plants. In this scenario the national PLF remains above $62.03 \%$ until 2024-25.

Companies with coal powered thermal plants will have to focus on changing their businesses portfolio towards greener ventures.

Another step that needs to be taken in the present situation is phasing out old thermal power stations. The power stations which have completed their life and are running at high Heat Rates (Low efficiency) must be phased out fast. Govt has already made announcements about this. India's Finance Minister Ms Nirmala Sitharaman has said in her budget this year (2020) that the government will advise utilities to close down thermal power plants if violating of National Clean Air Programme (NCAP). "Utilities running thermal power plants that are old and where the carbon emissions are higher will be advised to close down and that land will be used for alternative energy purposes, " said the Finance Minister detailing plans for environment and climate change in the Budget, report Aarushi Koundal \& Anshul Joshi, ET Energy World, (2020, Feb 01)[43]

Phasing out of old inefficient plants will not only reduce carbon emission from inefficient plants but will also enable the new high efficiency plants to be utilised at higher Capacity Utilization (PLF) levels.

Our analysis shows that if about $5000 \mathrm{MW}$ capacity is phased out every year and the demand and installed capacity mix happens as per the suggested projections of CEA, (Table 14) then the national PLF sustains at above $68.77 \%$ till 2024-25. Central sector will maintain PLF above $78.85 \%$ while State and Private sector touch $63.21 \%$ and $66.63 \%$ respectively.

In parallel, intensive research and policy support should be given to battery storage technology so that renewable is supported with storage techniques and can supply during peak periods also this relieving coal basd stations from peaking ramp up ramp down duties. 


\section{Conclusion}

Urgent review and reduction of fresh thermal capacity addition until 2024-25, immediately starting phasing out of old inefficient thermal power plants, policy and fiscal support to the power generator (if required through a separate fund, considering the ramp up and ramp down as ancillary service and providing policy and monitory support to thermal power because it is helping the renewable by providing ramp up ramp down support, urgent and strong reforms in the distribution sector are the ways to optimally utilise the thermal power plants. Otherwise many of the new, efficient thermal power assets created with large capital investment may face unsustainably low level of utilization and may become unavailable soon.

Meanwhile electricity storage technologies should be supported (along with renewable energy) with intensive R\&D, policy push and incentives so that renewable energy can sustain the grid when coal based generation is reduced.

\section{Limitations of this research}

1. Being a relatively new phenomenon in India, there is lack of data and understanding about the impact of various factors on Capacity Utilization (PLF) of thermal power plants in India. Some survey responders may therefore have used their intuition in deciding the factors.

2. It is assumed that electricity storage techniques would become available and would be cost effective in next five years and renewable energy coupled with storage cost per unit of electricity would be competing with thermal power cost. This would enable renewable energy being stored to meet the energy demand even when renewable plants are not generating. Rakesh Ranjan, Mercam India, (2020, June 02) [44] reported that in August last year (2019), SECI had floated a tender of for 1,200 MW solar-wind hybrid power with guaranteed supply during peak hours. Greenko won the auction for $900 \mathrm{MW}$, and ReNew won $300 \mathrm{MW}$. Greenko won the bid at a peak power tariff rate of ₹6.12 ( $\$ 0.08) / \mathrm{kWh}$ and ReNew Power won at ₹6.85 $(\sim \$ 0.09) / \mathrm{kWh}$. Many expect this tender to kickstart the commercial deployment of grid-scale storage in India. This price is higher than average cost of thermal power in India. For example, the average cost of NTPC Power stations in 2019-20 was Rs 3.79/kWh (Government of India Ministry of Power Rajya Sabha starred question no.244 answered on 17.03.20200 [45]. On the other hand, the coal based electricity cost is on the rise. Some of the new non pit head stations are already seeing a price band reaching Rs $5 \mathrm{kWh}$. The New Indian Express (2019, Dec 19) reports case of a large power station where tariff comes between Rs 5-6 /KWh. This study assumes that thermal power and renewable + storage cost will be comparable in next three years. If that does not happen, thermal power PLFs would sustain at a slightly higher level than predicted. If it happens earlier, PLF of thermal plants may see an even lower trajectory than predicted here. A separate study may be done considering the costs of thermal power vis a vis renewable and battery storage and then predict the effect on the thermal power.

3. All the major factors affecting Capacity Utilization (PLF) of power plants identified through this study cannot be modelled in regression because some factors are uncertain or qualitative in nature and their degree cannot be determined, viz, Financial health of power distribution companies, Environmental Norms.

4. Although the regression model had high R2, the factors considered for regression had high collinearity. Due to this, the Partial Least Square (PLS) method had to be used to predict the future values of PLF.

5. This paper has not studied the emissions arising out of the thermal power station. 
6. This paper has not studied the financial impact on the thermal power generators.

7. Time is the essence of this research. If the research is delayed it will lose value and utility immensely

\section{Figures, Tables and Annexures}

Table 01-Installed Capacity in India as on 31.03.2020

Table 02- Growth of power generation installed capacity in India 1947-2020

Table 03- Sector wise PLF in India 2009-10 to 2019-20

Table 04- Energy and Peak Deficit in India 2009-10 to 2019-20

Table 05- NTPC PLF and Declared Capacity (DC) 2005-06 to 2019-20

Table 06- Responses to Questionnaire

Table 07- Peak Demand, Installed Capacity of Coal and Lignite, Installed Capacity of Renewables and Thermal Power PLF- 1985-86 to 2019-20

Table 08- Regression Results using Excel

Table 09- PLS Regression results using $\mathrm{R}$

Table 10- Predicted Values - Scenario- BAU

Table 11- Predicted Values - Scenario- RG

Table 12- Predicted value - Scenario - LCAR

Table 13- Predicted Values Scenario - CEAS

Table 14- Predicted Values Scenario - CEAS + PHOUT

Figure 01- PLF of thermal power plants in India 1885-86 to 2019-20

Figure 02- REMSEP minimization chart- Result of analysis

Annexure -1 - Questionnaire

\section{Author contribution}

This paper has been entirely written by the single author Alok Kumar Tripathi

\section{Conflict of Interest}

This research is purely an academic work and there is no sponsorship, payment, engagement, alliance or influence or conflict of interest in this work. Author has written this paper in individual capacity and this paper does not represent company's view.

\section{References}

[1] Central Electricity Authority (CEA) Growth of electricity sector in India from 1947-2015 - www.cea.nic.in

[2] Central Electricity Authority (CEA) Annual Report - 2014-15-

http://www.cea.nic.in/reports/annual/annualreports/annual_report-2015.pdf

[3] Ministry of Power (MoP), Govt of India - http://powermin.nic.in/ 
[4] Ministry of Power (MoP). Working Group on Power - 12th Plan (2012-17), New Delhi 2012.

[5] CEA Report- Growth of Electricity Sector in India from 1947-2017

http://www.cea.nic.in/reports/others/planning/pdm/growth_2017.pdf

[6] NTPC Performance Data from Reports, Discussions \& Trainings collected through 2013- 2020

[7] Dash, Jayajit , Business Standard, (2019, July 15), Short-term power market gains as long-term PPAs recede, shows data -https://www.business-standard.com/article/economy-policy/short-term-power-market-gains-as-longterm-ppas-recede-shows-cerc-data-119071500676_1.html

[8] The Financial Express (2018, June 16), Renewable Power: New roadmap for mandatory purchase. https://www.financialexpress.com/industry/renewable-power-new-roadmap-for-mandatory-purchase/1208298/

[9] Power Engineering International (2020, March 23), New coal plants in India 'unviable' say economic analystshttps:/www.powerengineeringint.com/coal-fired/india-coal-fired-project-pipeline-poses-40bn-risk-in-asset-writedowns/

[10] Sengupta, D. (2016, Dec 20). Thermal power plants' Capacity Utilization (PLF) to drop to 48\% by 2022 [power]. The Economic Times. https://search.proquest.com/docview/1850192033?accountid=32554

[11] Wang, P., \& Li, M. (2019). Scenario analysis in the electric power industry under the implementation of the electricity market reform and a carbon policy in china. Energies, 12(11), 2152.

doi:http://dx.doi.org/10.3390/en12112152

[12] Wang, Y., \& Chen, J. (2019). The environmental effect of capacity utilization in thermal power plants: Evidence from interprovincial carbon emissions in china. Environmental Science and Pollution Research International, 26(29), 30399-30412. doi:http://dx.doi.org/10.1007/s11356-019-06251-2

[13] Robert, K. S. (2019). Analysis of hourly generation patterns at large coal-fired units and implications of transitioning from baseload to load-following electricity supplier. Journal of Modern Power Systems and Clean Energy, 7(3), 468-474. doi:http://dx.doi.org/10.1007/s40565-018-0470-9

[14] Luo, G., Zhang, X., Liu, S., Dan, E., \& Guo, Y. (2019). Demand for flexibility improvement of thermal power units and accommodation of wind power under the situation of high-proportion renewable integration-taking north hebei as an example. Environmental Science and Pollution Research International, 26(7), 7033-7047. doi:http://dx.doi.org/10.1007/s11356-019-04177-3

[15] Liao, S., Li, Z., Li, G., Wang, J., \& Wu, X. (2015). Modeling and optimization of the medium-term units commitment of thermal power. Energies, 8(11), 12848-12864. doi:http://dx.doi.org/10.3390/en81112345 [16] Bhardwaj, N., \& Sharma, D. (2020). Financial sustainability of Indian power sector: Curbing losses of distribution companies. Review of Integrative Business and Economics Research, 9, 166-184. Retrieved from https://search.proquest.com/docview/2386937929?accountid=32554

[17] Singh, S. K., Bajpai, V. K., \& Garg, T. K. (2013). Measuring productivity change in indian coal-fired electricity generation: 2003-2010. International Journal of Energy Sector Management, 7(1), 46-64.

doi:http://dx.doi.org/10.1108/17506221311316470 
[18] Draft National Electricity Plan, Volume I; (Central Electricity Authority, (CEA); Dec 2016). http://www.cea.nic.in/reports/committee/nep/nep_dec.pdf

[19] David Palchak, Jaquelin Cochran, Ali Ehlen, Brendan McBennett, Michael Milligan, Ilya Chernyakhovskiy, Ranjit Deshmukh, Nikit Abhyankar, Sushil Kumar Soonee, S.R. Narasimhan, Mohit Joshi, Priya Sreedharan, Greening the Grid: Pathways to Integrate 175 Gigawatts of Renewable Energy into India's Electric Grid, Vol. INational Study, a Joint Initiative by USAID and Ministry of Power.

[20] The Hindu Business line (2017), Thermal power plants hit by coal shortage Chatham: Newstex. Retrieved from https://search.proquest.com/docview/1961567383?accountid=32554

[21] Anupam Chatterjee, The Financial Express, (2018, Feb 23) Power Pipeline: Over 20,000 MW of projects face an uncertain future.

[22] The Mint, Thermal power sector starts seeing gains from slow capacity additions. (2018, Jun 12). https://search.proquest.com/docview/2053288157?accountid=32554

[23] Prasad, R. (2015, Jul 20). Power plant load slips to 59.43\% in June on account of poor demand [power]. The Economic Times Retrieved from https://search.proquest.com/docview/1697110709?accountid=32554

[24]Energy Monitor, (2016, Dec 21).Thermal power plants`Capacity Utilization (PLF) to drop to $48 \%$ by 2022 .. Worldwide. https://search.proquest.com/docview/1850714690?accountid=32554

[25] Xue, Y., \& Xiao, S. (2013). Generalized congestion of power systems: Insights from the massive blackouts in india. Journal of Modern Power Systems and Clean Energy, 1(2), 91-100. doi:http://dx.doi.org/10.1007/s40565-0130014-2

[26] Ian Salter, Plos One, (2018, Feb 23) https://journals.plos.org/plosone/article?id=10.1371/journal.pone.0192409 \& https://journals.plos.org/plosone/article/file?type=supplementary\&id=info:doi/10.1371/journal.pone.0192409.s001

[27]CEA, Draft report on optimal generation capacity mix for 2029-30.

http://cea.nic.in/reports/others/planning/irp/Optimal_generation_mix_report.pdf

[28] Sneha Alexander, The Mint (2020, March 18), Why the lights dimmed on UDAY ,https://www.livemint.com/news/india/why-the-lights-dimmed-on-uday-11584513638778.html

[29] David Fickling -Why India's Booming Power Market Is Bad for Business- Bloomberg Quint https://www.bloombergquint.com/view/coronavirus-india-s-power-generators-are-struggling-to-get-paid [30]Gopal K. Sarangi, Arabinda Mishra, and Farhad Taghizadeh-Hesary, DOES REGULATION PROMOTE SUSTAINABLE DEVELOPMENT OUTCOMES? EMPIRICAL EVIDENCE FROM THE INDIAN ELECTRICITY SECTOR- Asian Development Bank Institute, 1059, (2019)

[31]Anupam Chatterjee , Financial Express (2019, July 30)- https://www.financialexpress.com/economy/uday-schemediscoms-losses-rise-89-in y19/1660106/\#: :text=Discoms'\%20financial\%20losses\%20stood\%20at,provided\%20to\%20the\%20power\%20ministry.

[32] Office of the economic advisor of India - https://www.eaindustry.nic.in/display data 201112.asp)

[33] The Economic Times (2019, Dec 26)., Future of India's Green Fund from Coal. https:/economictimes.indiatimes.com/blogs/et-editorials/future-of-indias-green-fund-from-coal/ 
[34] Clyde Russell, Reuters, 2019, Feb 20 Coal going from winner to loser in India's energy future https:/www.reuters.com/article/us-column-russell-coal-india/coal-going-from-winner-to-loser-in-indias-energyfuture-russell-idUSKCN1Q90OP

[35] CEA- Norms for installation of FGD for new environmental regulations- 2015, Dec 07, http://www.cea.nic.in/reports/others/thermal/umpp/fgd_newnorms.pdf

[36] FICCI, Implementing New Emission Norms for Power Sector.

http://ficci.in/events/24114/Add_docs/Background-Note_Workshop-on-New-Emission-Norms-in-Power-Sector.pdf [37] India's NDCs, UNFCCC. https://www4.unfccc.int/sites/ndcstaging/PublishedDocuments/India\%20First/INDIA\%20INDC\%20TO\%20UNFCCC.pdf [38] Muhammad Tabish Parray and Rahul Tongia, Understanding India's Power Capacity (2019, August 28): Surplus or not, and for how long? - Brookings. https://www.brookings.edu/research/understanding-indias-power-capacitysurplus-or-not-and-for-how-long/

[39] The Economic Times, (2019, Oct 06). Delhi's power Discoms penalised by DERC for defaulting on green power obligations. https://economictimes.indiatimes.com/industry/energy/power/delhis-power-discoms-penalised-by-dercfor-defaulting-on-green-powerobligations/articleshow/71463254.cms?utm_source=contentofinterest\&utm_medium=text\&utm_campaign=cppst [40] CERC Tariff Regulation (2019, March 07). http://www.cercind.gov.in/2019/regulation/Tariff\%20Regulations2019.pdf

[41] Ankit Saproo, Economic Times, (2020, Jan 02). https://economictimes.indiatimes.com/news/et-explains/indiascoal-sector-output-is-back-in-the-black-heres-what-thatmeans/articleshow/73072396.cms?utm_source=contentofinterest\&utm_medium=text\&utm_campaign=cppst [42] Bilal Abdi \& Anshul Joshi, ET Energy World- (2020, Jan 03). https://energy.economictimes.indiatimes.com/news/power/how-the-economic-slowdown-has-dented-indias-powersector/73083261

[43] Aarushi Koundal \& Anshul Joshi, ET Energy World, Budget( 2020,2020, Feb 01): Govt will advise utilities to close down thermal power plants violating clean air norms https:/energy.economictimes.indiatimes.com/news/power/budget-2020-govt-will-advise-utilities-to-close-downthermal-power-plants-violating-clean-air-norms/73835014

[44] Rakesh Ranjan, Mercom India, (2020, June 02). Levelized Cost of Storage for Standalone BESS Could Reach ₹4.12/kWh by 2030: Report https://mercomindia.com/levelized-cost-storage-standalonebess/\#: :text=The $\% 20$ levelized $\% 20$ cost $\% 20$ of $\% 20$ storage $\% 20($ LCOS) $\% 20$ of $\% 20$ standalone $\% 20 \mathrm{BESS} \% 20$ is, $0.06 \% 2$ FkWh)\%20by\%202030.

[45] Government of India Ministry of Power Rajya Sabha starred question no.244 answered on 17.03.2020

[46] The Indian Express (2019, Dec 19), https://www.newindianexpress.com/cities/chennai/2019/dec/19/tns-largest4000-mw-cheyyur-thermal-plant-proposed-near-chennai-among-indias-top-12-non-performin-2077983.html 


\section{Annexure 1}

\section{Research Questionnaire}

As you are aware, utilisation factor [PLF] of coal based thermal power station in the country has a seen a consistent downward trend in last few years and the future outlook is also not very clear. This situation is affecting the power producers, lenders, Discoms, consumers and almost everybody else connected with power sector. This research is an attempt to find out the factors that are responsible for capacity utilisation of coal based plants in India so that they can be addressed and future trend can be predicted.

We seek your expert opinion about rating of factors that are responsible for downward trend/low capacity utilisation of coal based thermal power in India. Please rate the following based on your understanding/ experience.

Please rate the factors as per your opinion whether the factor has -

- Having very high impact

- Having high impact

- Neutral or undecided

- Having low impact

- Having very low impact

1.1) Poor financial health of power procuring companies (Discoms) is forcing them to reduce power procurement even if while demand exists, is a factor affecting coal based thermal power Capacity Utilization (PLF) in India.

1.2) The power utilities of state sector (State Gencos ) are in financial distress and are unable to maintain their own power plants in good condition which is a factor affecting coal based thermal power Capacity Utilization (PLF) in India.

1.3) The power utilities of private sector (IPPs) are in financial distress and are unable to maintain their own power plants in good condition which is a factor affecting coal based thermal power Capacity Utilization (PLF) in India.

1.4) Due to large number of thermal power loans becoming NPA, banks have reduced lending creating fund crunch for power producers which is a factor affecting coal based thermal power Capacity Utilization (PLF) in India.

1.5) Generating electricity from coal is no longer attractive business due to rising costs, forcing the thermal generators to cut down generation which is a factor affecting coal based thermal power Capacity Utilization (PLF) in India.

2.1) New emission norms set by Govt in 2015 for thermal power plants is a factor affecting thermal power Capacity Utilization (PLF) in India

2.2) Society's growing concern about environment is forcing power stations to reduce production and is a factor affecting thermal power Capacity Utilization (PLF) in India

3.1) Disproportionately high share of thermal power in Indian grid $(63.7 \%$ of total installed capacity as on 31.03.2019) is a factor affecting coal based thermal power Capacity Utilization (PLF).

3.2) Substantial addition of renewable energy (solar and wind) having must-run status in the grid is a factor affecting coal based thermal power Capacity Utilization (PLF).

4.1) Grid evacuation constraint (line loading limitations) in some areas causing reduction in power generation is a factor affecting coal based thermal power Capacity Utilization (PLF). 
5.1) The thermal power plants are experiencing forced outages // technical problems (like boiler tube leakages etc) and are unable to generate to full capacity which is a factor affecting coal based thermal power Capacity Utilization (PLF) in India.

5.2) Many thermal power plants in India are ageing and are unable to reach full load capacity which is a factor affecting coal based thermal power Capacity Utilization (PLF).

5.3) The thermal power plants were designed as base load (full load) operation whereas the grid conditions today demand flexible operation that coal plants are unable to cope up which is a factor affecting coal based thermal power Capacity Utilization (PLF) in India.

6.1) Low growth of power demand in the country as compared to projected is resulting in underutilisation of thermal power and is a factor affecting coal based thermal power Capacity Utilization (PLF) in India.

6.2) India has reached a stage of being power surplus (on most days in a year) which is a factor affecting coal based thermal power Capacity Utilization (PLF) in India.

6.3) Although India is power deficit on totality basis, many regions have actually become power surplus which is a factor affecting coal based thermal power Capacity Utilization (PLF) in India.

6.4) Large number of players in power generation is resulting in fierce competition and is a factor affecting coal based thermal power Capacity Utilization (PLF) in India.

6.5) After opening up of power sector, many new and inexperienced players jumped without understanding the electricity market which is a factor affecting coal based thermal power Capacity Utilization (PLF) in India.

7.1) Low fuel (coal) availability forcing thermal power generators to reduce power generation and is a factor affecting coal based thermal power Capacity Utilization (PLF) in India.

7.2) Poor quality of coal having very high ash is forcing thermal power generators to reduce power generation and is a factor affecting coal based thermal power Capacity Utilization (PLF) in India.

8.1) The tariff / policies are un-supportive of thermal power generators which is a factor affecting coal based thermal power Capacity Utilization (PLF) in India.

8.2) Renewable energy is getting promoted at the cost of thermal generators because thermal plants are supposed to generate when nobody else is able to generate and then back down when others are available, this is a factor affecting coal based thermal power Capacity Utilization (PLF) in India.

8.3) There is lack of policy clarity on whether and how old thermal power plants are to be retired, which creates a dilemma whether to invest in their R\&M and is a factor affecting coal based thermal power Capacity Utilization (PLF) in India.

8.4) The Ultra Mega Power scheme did not bear desired results because of policy issues (projects risks were not addressed properly) which is a factor affecting coal based thermal power Capacity Utilization (PLF) in India.

9 ) There is a general perception that coal based thermal power will be entirely phased out in the medium / long run which is inhibiting new and modern technology infusion in thermal plants and is a factor affecting coal based thermal power Capacity Utilization (PLF) in India.

Any other factor/factors that you feel plays or will impact Capacity Utilization (PLF) of thermal power in India. (Please also specify the factor and mention in bracket - Very high impact/high impact/low impact / very low impact, as the case may be) 